\title{
The U.S. Beer Market: A Competitive Profile
}

\author{
Y. Datta ${ }^{1 *}$ \\ ${ }^{1}$ Professor Emeritus, Northern KY University, Highland Heights, KY, USA \\ *Y. Datta, E-mail: Ydatta88@gmail.com
}

Received: November 16, 2017 Accepted: November 22, 2017 Online Published: November 27, 2017

doi:10.22158/jepf.v3n4p541

URL: http://dx.doi.org/10.22158/jepf.v3n4p541

\begin{abstract}
Porter equates high market share with cost leadership strategy which is based on the idea of competing on a price lower than that of the competition. However, customer-perceived quality-not low cost-should be the underpinning of competitive strategy, because it is far more critical to long-term competitive position and profitability than any other factor. So, a superior option is to offer better quality vs. the competition.

In most consumer markets a business seeking market share leadership should cater to the middle class by competing in the mid-price segment: and offering better quality than that of the competition at a somewhat higher price.

Quality, however, is a complex concept consumers generally find difficult to understand. So, they often use relative price and a brand's reputation as a symbol of quality.

The U.S. Beer market is one of the most complex industries. It has two product-segments: Lager and Ale, with lager being the overwhelmingly dominant segment. Also, it has three market groups: Traditional, Imports, and Craft.

We have focused most of our statistical analysis on the lager segment. First, we tested the hypothesis that a market leader is likely to compete in the mid-price segment. Second, the price tag of the market leader is going to be somewhat higher than that of the nearest competition. Employing U.S. retail sales data for 2008 and 2007, we used cluster analysis based on unit price of 12-packs and six-packs (Note 1). The results strongly supported both hypothesis for both years-and for both packs.

We have proposed an alcohol-based system for classifying beer: Low vs. High. This proposal is based on the premise that alcohol and calories are closely tied to each other. We performed bivariate correlation on 50 popular lager and ale brands, and the results were significant at the 0.01 level.
\end{abstract}

Finally, we discovered five strategic groups in this market.

\section{Keywords}

U.S. Beer market, cost leadership, price-quality segmentation, market-share leadership, relative price a strategic variable, strategic groups, alcohol-based beer classification system 


\section{Introduction}

This work follows in the footsteps of the study of U.S. Men's Shaving Cream Market (Datta, 2012). That research is based on the premise that the road to market share leadership does not lie in lower price grounded in cost leadership strategy, as Porter (1980) suggests. Rather, it is based on the idea - according to the PIMS database research — that it is customer-perceived quality that is vital to long-term competitive position and profitability. So, the key to market share leadership for a business is to differentiate itself by offering quality that is better than that of the nearest competition (Datta, 2012). To make this idea operational requires two main steps. The first step is to decide which price-quality segment to compete in? Most consumer markets can be divided in three basic price-quality segments: premium, mid-price, and economy. These can be extended to five by adding two more: ultra-premium and ultra-economy. The answer lies in serving the middle class by competing in the mid-price segment. This is the socio-economic segment that represents about $40 \%$ of households in America. It is also the segment that Procter \& Gamble - the top global consumer products company-has successfully served in the past (Datta, 1996, 2012).

\subsection{Strategic Importance of Price Positioning}

The second step is to position the brand at a price that is somewhat higher than that of the closest competition in the mid-price segment. This is required for two reasons: (1) to promote an image of quality; and (2) to make sure that the strategy is profitable and sustainable (Datta, 2012, 2010a, 2010b). A classic example of price positioning is provided by General Motors (GM). In 1921 GM rationalized its product line by offering "a car for every purse and purpose"- from Chevrolet to Pontiac, to Oldsmobile, to Buick, to Cadillac. More importantly, GM positioned each car line at the top of its segment (Datta, 1996, 2010a).

A more recent and well-known example is the economy chain Motel 6 which has positioned itself as "offering the lowest price of any national chain". Another case is Fairfield Inn. When Marriott introduced this new chain, it targeted it at the economy segment. And then it decided to position it at the top of that segment (Datta, 1996).

\subsection{Close Link between Quality and Price}

As mentioned above, customer perceived quality is the most important variable contributing to the long-term success of a business. However, quality cannot really be separated from price (Datta, 1996). Quality, in general, is a complex multi-dimensional concept that is not easy to understand. So, consumers often use relative price—and a brands' reputation—as a symbol of quality (Datta, 2012, 2010b).

\section{U.S. Beer Industry: Brief History and Technology}

\subsection{Origin of Beer}

Around 10,000 BC Neolithic people, in what is now called Kurdistan, began to use grasses as a good source of nutrition. These grasses eventually turned into barley and wheat. It is this time that marks the 
beginning of agriculture (Mosher, 2009, p. 6).

By 3,000 BC, Egyptians had found that barley was the best grain for brewing. Around 2,000 BC, Celts were brewing with barley, wheat, and oats (Webb \& Beaumont, 2012, p. 15).

\subsection{How Beer is Made}

Beer is the third most popular drink after water and tea (Oliver, 2012, p. i). It belongs to a family of starch-based alcoholic beverages produced without distillation. Today beer is brewed predominantly from barley malt and seasoned with hops. However, other grains—called adjunct grains—such as, rice, corn, wheat or oats-may also be used (Mosher, 2009, p. 5).

Malt is considered as the soul of beer. Malting is a process that keeps the grains warm and damp so that they can germinate. But then they are prevented from further germination and are dried with hot air. This action produces enzymes that convert barley's starch into sugars-called wort-that can then be fermented into alcohol (AB-InBev. Retrieved November 16, 2017, from http://www.anheuser-busch.com/about/brewing.html).

A major challenge of the early brewers was oxidation. Hops contain antioxidants that slow down acidification, and antiseptics that lower fungal and other infections. So, hops became the ideal choice of brewers to address this problem (Webb \& Beaumont, 2012, p. 15).

While malt is known as the "soul" of beer, as mentioned above, "[h]ops are known as the "spice" of beer, adding to beer's aromas and bitterness to balance the sweet malt flavors" (AB-InBev. Retrieved from http://www.anheuser-busch.com/about/brewing.html).

Yeast is another ingredient which plays an important role in the final process of making beer. It metabolizes wort, and produces ethanol, carbon dioxide, and much smaller amounts of other chemicals (Mosher, 2009, p. 53). However, its contribution to beer's flavor is often not fully appreciated. With the proliferation of different styles of beer in the industry, the ability to continuously monitor and experiment with yeast levels can enable a brand to differentiate itself from the competition (Quality In. Quality Out. Retrieved from http://www.anheuser-busch.com/about/brewing.html).

Malt is roasted in several varieties. At the lighter end is pilsner malt that is used in creating light, blond beers. Pale ale malt produces an amber hue. Slightly darker malt brings in the color of toffee, while Vienna and Munich malts create a ruddy brown tint. Finally, chocolate malts look-and taste - caramelized, which generally makes the beer black and bitter (Webb \& Beaumont, 2012, p. 17). There are two major categories of beer: lager and ale. Lagers are made with bottom-fermented yeast and aged at close to freezing temperatures that require a longer maturation period. Ales, on the other hand, are produced with top-fermenting yeast at warm temperatures: between $65^{\circ}$ and $73^{\circ} \mathrm{F}$. At these higher temperatures yeast produces a lot more of the "fruity aroma molecules called esters and other chemicals that add spicy, fruity complexity to beer" (Mosher, 2009, p. 237, p. 169, p. 181; italics added).

\subsection{Beginning of the U.S. Brewing Industry}

The origin of brewing in America dates back to the first settlements established by the English and the 
Dutch in the early- to mid-seventeenth century (Stack, 2010). However, the seeds of the modern industry in America were sown during the middle of the 19th century, when a large number of German immigrants arrived in the U.S. and "set about re-creating the pleasures of biergartens they had left behind". This was the time when rum and whisky were the most popular alcoholic drinks in the U.S. And just fifty years later, American-style lager was the most popular beverage, and brewing was the fifth largest industry in the country (Ogle, 2006, front cover).

\subsection{Birth of the American Adjunct Pale Lager}

In the 1860 s and early 1870 s American brewers were facing some difficulties. Due to the growing popularity of beer, American farmers were finding it difficult to cope up with the brewing industry's demand for barley. Several years of bad weather had further worsened the problem. At that time most American brewers were making Bavarian (German) style beer using six-row barley. This all-malt beer was extremely rich in protein. In addition, it was both unstable and had a short shelf life (Ogle, 2006, pp. 70-71; Talley, 2017, p. 76).

Germans were used to an overcrowded land where food was often in short supply. So, for centuries Germans and other Europeans thought of beer as food: "liquid bread". But, Americans "relegated that idea to the dustbin of antiquity". In contrast, America was a land of plenty with high crop yields, and protein-rich diets. So Americans did not need to drink beer for food (Ogle, 2006, p. 72).

Whereas, Germans would nurse a mug of beer for hours, Americans just wanted "to drink". While the old-world enthusiasts emphasized the nourishing qualities of Bavarian beer, Americans drank beer "to pass time pleasantly in jovial company". Also, the Americans didn't like the Bavarian lager because they thought it was "too heavy, too filling, and...too brown". Instead, they demanded a "light sipping" beer somewhere between "light wine and the heavy Bavarian lager" - a beer that "sat light on the stomach" (Ogle, 2006, pp. 72-73).

It was Bohemian pilsner lager from Czech Republic that provided a potential answer to this problem. Anton Schwartz, who had migrated from Bohemia to America, began-along with Dr. John Siebel—experimenting with malt adjuncts and publishing their results. Based on their research, they reported that "malt adjuncts did not make an inferior beer" (Talley, p. 75; italics added).

Following the expert advice of Schwartz, Adolphus Busch embarked upon an adventure to create an American version of Bohemian lager. Schwartz expressed a preference for rice over corn: because rice, unlike corn, hardly contains any oil (Ogle, 2006, p.75).

Another factor that led Adolphus Busch to add rice as an adjunct is that he believed it imparted crispness and clean taste to beer. Still another reason is that he wanted to set Budweiser apart from its competition. Before 1876 Americans were drinking "heavy dark ales". So he created Budweiser because he thought its "smoothness and drinkability" were perfect for hot summers of St. Louis (Quality In. Quality Out. Retrieved November 21, 2017, from http://www.anheuser-busch.com/about/brewing.html; An Ambitious Legacy. AB-In-Bev. Retrieved November 21, 2017, from http://www.budweiser.com/en/our-brand/our-legacy.html). 
Thus, thanks to the entrepreneurship of Adolphus Busch, the first American Adjunct Lager was born that he named Budweiser (Ogle, 2006, p. 78)!

Budweiser was "yellow in color, with a brilliant sheen, light bodied with a foamy head, and a rich almost creamy flavor". Although it cost more than Bavarian all-malt beers, the brewers soon found out that the Americans liked the new creation (Ogle, 2006, p.75).

This new beer was so successful that it "changed the face of American brewing for all time and did so almost overnight" (Ogle, 2006, p. 78; italics added)!

The Americans "embraced the new beer with open hearts - and mouths". They didn't like the "sour" and "bitter" taste of all-malt beer, preferring instead the "sweeter" flavor of light-bodied pale Bohemian beer-and its "rich creamy froth". Americans had become so fond of a light- colored beer that a darker beer was regarded as inferior or even of bad quality (Ogle, 2006, p. 85).

The "late nineteenth century belonged to pale, adjunct-based lager", and "barons [of the industry] built their fortunes on the foundation of its golden broth" (Ogle, 2006, p. 85). The momentous nature of this historic development can be gauged by the fact, that even today more than $80 \%$ of all beer sold world-wide is the pale lager style (Nachel \& Ettlinger, 2012, p. 54).

\section{The U.S. Beer Industry in the 20th Century}

Beer did not become a mass-produced mass-consumed product until long after the American Civil War. Total production went up from 3.6 million barrels in 1865 to over 66 million barrels in 1914 (Stack, 2010).

The brewing industry faced a big setback in 1919 when national prohibition came into effect with the passage of the 18th Amendment to the U.S. Constitution. However, this law was abolished in 1933 via the 21st Amendment (Beer Advocate, 2013).

The first temperance anti-drink crusade began in the 1820s. Since then it has infused drinking alcohol with a blemish and "disrepute that has never gone away" (Ogle, 2006, p. 25).

The period following WW II witnessed great industry consolidation. In 2000 the top-three U.S. breweries were: Anheuser Busch (A-B), Miller, and Coors with a market share, respectively, of 50\%, $20 \%$, and $11 \%$ (Stack, 2010).

\subsection{The Sad Story of Schlitz-The Importance of Quality}

In 1970 Schlitz was the number two brewer in America. To improve its profitability Schlitz embarked upon a strategy what Porter (1980) later characterized as cost leadership (Datta, 2010a, 2010b).

Schlitz followed a three-pronged approach to implement this strategy: (1) Build new breweries that were four times as large as any that had been built before, (2) The company devised a new brewing process that it called "accelerated" batch fermentation that cut down fermentation from twelve days to less than four, (3) It quietly began to use cheaper or artificial ingredients to cut its costs by partially replacing barley malt with corn syrup, and using hops extract and hops pellets for fresh hops (Knoedelseder, 2012, p. 116). 
As a result of its cost leadership strategy, Schlitz was producing its beer at a much lower cost than A-B (Knoedelseder, 2012, p. 116). Soon, it became a darling of Wall Street in the brewing industry. Forbes magazine reported that in 1973 Schlitz's return on stockholder equity of $21 \%$ far exceeded the $13 \%$ of A-B. The magazine criticized A-B for being "out of touch with modernity", and asked that if the job of top management is to "make money for the stockholders...". shouldn't A-B be "paying more attention to the dollar sign" (Knoedelseder, 2012, pp. 127-128).

However, this reckless pursuit of cost leadership strategy led to a serious erosion of quality that turned out to be fatal. In a few years, "the beer that made Milwaukee famous" virtually disappeared from the market (Knoedelseder, 2012, p. 144).

In sharp contrast, Gussie, A-B's CEO, said where quality is concerned there can be no compromise, and that there will be no change in Budweiser's brewing process as long as he was in charge (Knoedelseder, 2012, pp. 127-128).

In our opinion, the role Wall Street played in the demise of Schlitz cannot be minimized. The U.S. financial system largely focuses on short-term appreciation of shareholders equity at the expense of long-term performance (Porter, 1992; Datta, 2011). This mind-set is eloquently captured in the following passage that appeared in Advertising Age at that time (Knoedelseder, 2012, p. 145):

A classic tale of human failing, the Schlitz saga now serves as a reminder for those who might lose sight of the fact that a company-no matter how modern its plants, how endowed its balance sheet or how lionized by Wall Street analysis-is really no stronger than the human beings who manage it.

\section{Fragmentation of the U.S. Beer Market}

\subsection{Americans Switch to Bland Processed Food}

A crucial change occurred in the first half of the twentieth century. Looking back at the past, Americans realized that they did not like the idea of their mothers and grandmothers toiling long hours making food in the kitchen. Associating modernity with convenience, they gave up flavor and nutrition of home-cooked food for bland processed food: e.g., canned soups, vegetables, fruit; factory-made Wonder Bread: light and textureless; "instant" coffee, TV dinners, and so on (Ogle, 2006, pp. 228-229). Nevertheless, more a food is processed the more it loses its flavor; moreover, processing adds extra sugar to food (Ogle, 2006, p. 228).

Yet, one important reason for processing food is the need to preserve it. However, industrial processing goes far beyond extending food shelf life. Instead, it is particularly calculated to "sell us more food by pushing our evolutionary buttons - our inborn preferences for sweetness and fat and salt" (Pollan, 2008, pp. 149-150; italics added).

In early 1950s sophisticated consumer research indicated that the new generation of American consumers did not like "overtly malty or hoppy beers". So, as Adolphus Busch had done way back in 1876 , the barons of beer industry once again came through to give the customers what they wanted (Ogle, 2006, p. 229). 
As a result, the "Master Brewers Association" began telling their members to brew beer with pale color: "an agreeable, mild hop flavor", and "no bitter after-taste" (Ogle, 2006, p. 229).

A Gallup survey conducted in 1954 projects a consumer preference profile similar to the one we have reported above. The survey found that the eating habits of Americans were "dull". The "overwhelming choice of most Americans for dinner-if cost were no object—was fruit cup, vegetable soup, steak, french fries, and apple pie a' la mode". Also, by 1950 "class differences were declining in clothing, autos, food, and even personal hygiene" (Datta, 2011).

\subsection{The Role of High Fructose Corn Syrup (HFCS)}

In the early 1970s Nixon administration told American farmers that the government would pay them for all the corn they could produce. One result of this policy was that the increasing output drove the price of corn down. While the cheap corn fattened the profits of agribusiness, it forced a lot of family farms out of business (Pollan, 2008, pp. 121-122; Pollan, 2009, pp. 38-39).

Americans consume most of the 58 pounds of HFCS in soft drinks. In 1980, a memorable year for corn, Coca Cola and Pepsi switched over from sugar to HFCS. This is because HFCS was much cheaper than sugar and consumers couldn't tell the difference between the two. But, instead of reducing cola prices Coke and Pepsi chose a different path: increase the size of cola bottle (Pollan, 2009, p. 80; for a glimpse of America's dysfunctional food culture, see Datta, 2010c).

Finally, it is important to reiterate one factor that has had a major impact on American consumers' palate — and their preference for the kind of beer they like. And that factor is: sugar!

\subsection{Increasing Economic Inequality in America Since 1974}

From 1942 to the mid-seventies a great leveling of incomes occurred between classes in America. However, since 1974 the middle class has been on a relentless economic squeeze. In particular, median household income declined in the 1999-2008 decade: an event that had never happened in the past four decades. In 2008, American income inequality touched or even exceeded the lofty heights before the Great Depression of 1929 (Datta, 2011).

Long-term demographic changes, triggered by social movements and changing social mores, accentuated economic inequality. One was a steady increase in American divorce rate that had a damaging effect on divorced women, who usually ended up with the responsibility of supporting their children. Thus, many fell out of the middle class: an important factor in the feminization of poverty (ibid).

Second, with the widespread entry of women in the workforce, a new marriage pattern emerged. In the past it was common for an executive to marry a pretty secretary, or for a doctor to marry a nurse. Now an executive is much more likely to marry another executive, or a professional. Likewise, a doctor is more likely to marry another doctor, not a nurse (ibid).

An important effect of this mounting economic inequality is a vast increase in the size of upper middle class. In 2008 the lowest two percentiles were occupied by "The Poor" and the "Near Poor", respectively. The next two belong to the "Traditional Middle Class", while the "Upper Middle Class" 
has claimed the $80-99.5 \%$ percentile (Datta, 2011).

\subsection{From a Mass to a Class Market}

During the post-World-War-II period 1947-1973, America experienced a sustained period of widespread prosperity. By the end of the 1970s American consumers had become tired of the standardized goods churned out by the nation's vaunted mass-production machine (Datta, 2011).

This is the time when America had reached a stage where the "era of bland food was grinding to a halt" (Ogle, 2006, p. 251). Symbolizing this trend was the opening in 1971of the first Starbucks which introduced Americans to "some of the world's finest fresh-roasted whole bean coffees": at a premium $\begin{array}{lllll}\text { price } & \text { (Starbucks. } & \text { Retrieved } & \text { November } & \text { 16, 2017, from }\end{array}$ http://www.starbucks.com/about-us/our-heritage).

Another notable development in fragmentation of the U.S. mass market was the opening of two major discount chains in 1962 - Wal-Mart and K-Mart — that aimed at catering to the economy segment. Thus, the mass market of yesterday was fragmenting into a class market of today (Datta, 1996, 2011).

\subsection{Profound Influence of Upper Middle Class over U.S. Beer Market}

In response to competition from the imports, as discussed later, A-B decided in 1966, to relaunch Michelob as the first national premium beer brand (Datta, 1996; also Ogle, 2006, pp. 251-252).

The traditional American beer market had not changed much since the revolutionary introduction of American Adjunct Pale lager-Budweiser-in 1876, as mentioned earlier. However, a major change occurred in 1967 with the birth of light beer. Two other factors further contributed to the fragmentation of the U.S. beer market: the emergence of the import and craft segments, all of which had a profound impact on the U.S. beer market.

The upper middle class consists mostly of professionals. They are more likely to engage in foreign travel and have a cosmopolitan taste. But, most importantly, their lifestyle and opinions exert considerable influence over the entire society (Datta, 2011).

We submit that the upper middle class played the primary role in giving rise to two transformative events in the U.S. beer industry: the birth of the import and craft markets.

\subsection{The Phenomenal Success of Light Beer}

Diet or low-calorie beer was originally offered by Meister Brau in 1967 with the brand name Lite. Miller acquired the rights to it in 1972. During this period, consciousness of healthy eating had become popular: and with that the demand for beer with lower calories. Using the marketing expertise of its parent, Philip Morris, Miller took a "female oriented brand and restaged it with a shot of testosterone" (Mosher, 2009, p. 23).

So Miller came up with a brilliant advertising campaign aimed at 18-34 blue-collar men who were heavy beer drinkers. The company positioned it as a beer that "tastes great has less calories" As a result, Miller was able to catapult itself from fourth to second place in 1977 (Ogle, 2006, p. 249, p. 283).

So spectacular was the growth of this segment that by 2005 light beer production had bypassed regular beer (Mosher, 2009, p. 23). 


\subsection{Growth of Imported Beer}

Imports were less than one percent of total U.S. beer sales in the 1960s. However, during the first half of the 1970s, imports grew 88\%. This was the time when Americans-young baby boomers and affluent middle-aged - began to travel to Europe in large numbers. When they returned home they had developed a taste for European-style beers which were being sold at premium prices in America. However, for some people, it was the snob appeal of imported beer. It didn't matter whether or not imported beer was better than American. The "import" label allowed these drinkers to "thumb their noses at the establishment", and to "assert their sophistication and worldliness" (Ogle, 2006, p. 250, pp. 275-276).

The "sudden popularity of imports marked the onset of a transformative moment" in the history of the American beer industry (Ogle, 2006, p. 251)! From a share of just $1 \%$ of total U.S. beer sales in the 1960 s, imports have climbed all the way to $21 \%$ in 2008 , as per our data.

\subsection{AB-InBev's Aggressive Pursuit of the Import Market}

Realizing the growth potential of this premium segment, Anheuser Busch has acquired many imports. The most popular among them are Stella Artois, St. Pauli Girl, Beck's, Foster's, Kirin, and Bass (ale). However, the last four are now brewed in USA, and can therefore only be called "former imports" $\begin{array}{lllll}\text { (AB-InBev } & \text { Retrieved } & \text { November } & 16, & 2017,\end{array}$ http://www.ab-inbev.com/content/dam/universaltemplate/ab-inbev/investors/presentations-pdf-archive/ presentations/2013/13_Adam_Oakley-HighEnd.pdf).

\subsection{The Emergence of Craft Beer and Microbreweries}

Another crucial development in the industry is the emergence of craft beer. As of June 30, 2017 a total of 5,562 microbreweries were operating in the U.S. In 2016 its share of the U.S. beer market by volume was $12.3 \%$. From a torrid growth rate of $18 \%$ by volume in 2013 , craft beer volume grew only $5 \%$ during first half of 2017, indicating a maturing market (Gribbins, 2017) (Brewer Association. Retrieved November 15, 2017, from https://www.craftbrewingbusiness.com/featured/craft-beer-growth-showsslowing-maturing-market/).

\subsection{The Pioneering Role of Anchor Brewing Co.}

The introduction of Steam Beer by Anchor Brewing in 1965 is generally regarded as the beginning of the craft-brewing movement in America (Mosher, 2009, p. 25).

Fritz Maytag noticed that many Americans were drinking imported beer that cost even more than the priciest domestic beers. As such, he targeted his business strategy at this small segment of discriminating beer drinkers who were now being served by the imports (Ogle, pp. 264-265).

Maytag realized that there was an "audience eager for authenticity", and that the American public was ready for a new kind of beer: an "older style of full-bodied" beer that had not been produced in America for more than a century (Ogle, 2006, p. 265).

Maytag's readiness to act on that belief "signaled a transformative moment in American brewing" that would inspire a new generation of brewers (Ogle, 2006, p. 265; italics added). 


\subsection{The Brewers Association (BA): Defining Craft Beer}

BA is an association of small and independent craft brewers. It says a craft brewer is small, producing less than 3\% of annual U.S. sales. Second, the brewer should be independent, such that less than $25 \%$ is owned by a company that is not a craft brewer. Finally, craft beer is "generally made with traditional ingredients like malted barley; interesting and sometimes non-traditional ingredients are often added for distinctiveness" (italics added) (Retrieved November 16, 2017, from https://www.brewersassociation.org/statistics/craft-brewer-defined).

\subsection{The Special Case of Yuengling}

In 2014, BA announced a change in its criteria for making craft beer. Previously, traditional brewers had to use malted barley. However, now a traditional brewer can use adjuncts, such as corn or rice, so long as it is meant to enhance flavor. This change allowed Yuengling, America's oldest brewery - founded in 1829- to be recognized as a craft beer. As a result, Yuengling became the largest craft brand overtaking Samuel Adams (USA Today, 2015).

However, in our opinion the above story does not represent the full picture. In 2008 Yuengling's sales of its amber-red lager were over $85 \%$ of its total lager sales. This "all-malt" beer did not have any adjuncts and fully met the earlier basic building block of craft beer, as we have mentioned before (Retrieved November 17, 2017, from https://www.yuengling.com/our-beer/).

\subsection{AB In-Bev and Molson Coors Dive into the Craft Market}

To take advantage of this rapidly growing premium segment, AB-InBev has purchased many craft brewers. A notable example is acquisition of a 32.3\% share in Craft Brew Alliance (Taylor, 2017). Molson Coors, too, has bought two craft breweries. Nevertheless, because these former craft brands do not meet the definition of BA's craft beer, their names have been removed from its membership.

Another track the two companies have pursued is to offer a home-grown craft-like beer. One is Molson Coors' popular Blue Moon Ale. The other is AB-In-Bev's Shock Top Ale.

\section{Globalization and Further Consolidation of the U.S. Beer Industry}

During the late 1980s A-B began to move cautiously in foreign markets. In the 1990s A-B secured a foothold in three of the world's biggest potential markets with a 10\% share in China's largest brewery, Tsingtao; a 37\% stake in Grupo Modelo, Mexico's largest brewery; and a 10\% share in Antarctica, Brazil's second-largest brewery (Knoedelseder, 2012, p. 297).

Due to A-B's continued domination of the U.S. brewing industry, Philip Morris, the parent of Miller, finally decided to "throw in the towel"- thirty one years after its entry in the market. In 2002 it sold Miller to London-based South African Breweries Ltd (SAB). The new company was to be known as SABMiller (Knoedelseder, 2012, p. 296).

Earlier, A-B had passed up a chance to acquire South African Breweries (SAB) before the company began to gobble up smaller breweries in Central Europe that enabled it to become a global player capable of pulling off a multibillion dollar acquisition of Miller (Knoedelseder, 2012, p. 297). 
Before it bought Miller, SAB was the world's fourth largest brewer, but thereafter SABMiller became the second largest behind A-B. But, A-B's ranking was based on the volume of its beer produced, 90\% of which was sold in the U.S. While this made A-B a "powerhouse domestically", it was a “comparative weakling overseas" (Knoedelseder, 2012, p. 296).

In 2005 Coors, America's third largest brewer, merged with Molson, Canada's largest, forming a new company, Molson Coors. In 2007 SABMiller and Molson Coors, the number two and number three U.S. brewers, respectively, announced that they were integrating their American operations to better compete with A-B (Knoedelseder, 2012, p. 298, p. 318).

In 2008, IN-Bev, a four-year old Belgium-based company controlled by three Brazilian billionaires, made an unsolicited - and unwelcome - bid to acquire Anheuser-Busch. This became the biggest cash acquisition in history. As a result, "America had lost one of its most beloved companies"- the last "freestanding, independent company, still operated by the family that founded it" (Knoedelseder, 2012, p. 3, p. 6).

Due to anti-trust concerns, A-B InBev had to sell Grupo Modelo's U.S. business in 2013 to Constellation Brands, a U.S. company. That included a permanent license to import,market and sell Mexican brands like Corona, Modelo, Pacifico, and Negra Modelo (Retrieved November 16, 2017, from http://www.cbrands.com/our-brands/beer).

In 2015 AB-InBev agreed to merge with SABMiller. As part of this deal, SABMiller consented to sell the global rights to its Miller brand to Molson Coors. The major benefit for AB-InBev from this merger is the higher growth opportunities that SABMiller brings to this union in the growing markets of Asia, Africa, and Latin America (Forbes, 2015).

The U.S. antitrust department approved the $\$ 101$ billion merger. In addition to divestiture of the Miller brand, AB-InBev also agreed not to stifle competition from craft brewers (McLaughlin, 2016).

\section{U.S. Beer Industry: Price-Quality Segmentation Profile}

This study is based on U.S. retail sales for 2008 and 2007 (Note 2). The data includes total dollar and unit sales, no-promotion dollar and unit sales, and promotion (Note 3) dollar and unit sales. Total U.S. retail beer sales for 2008 were $\$ 9.5$ billion: of this lager sales were a whopping $92.3 \%$, but ale a relatively tiny $7.7 \%$.

\subsection{Traditional, Import, and Craft Market Segments}

The U.S. Beer industry can also be divided in three market groups:

- In addition to current imports, the "Import" group also includes former import brands, like Beck's, that are now brewed in USA.

- The "Craft" group encompasses former craft brands, home-grown craft-like brands like Blue Moon, as well as craft brewers that are currently members of BA.

- The Traditional group includes leading brands like Bud Light, Miller Light, Budweiser, Coors, and others, but excludes those that do not fall into either the Import or the Craft groups. 
Now we present three pie charts (Note 4) (Figures 1-3) on the next page. They show, for each market segment, market shares of 2008 beer sales for: (1) Total Beer, (2) Lager, and (3) Ale.

The major highlights of the picture revealed by these charts are as follows:

- Not surprisingly, the Traditional group stands out as the overwhelmingly dominant segment, with a $68 \%$ share of the total beer market, and a $74 \%$ share of the lager market.

- Interestingly, the "Import" group's $22 \%$ share of the lager segment is not far behind its $24 \%$ share of the ale segment.

- While the "Craft" group has only a $4 \%$ share of the huge lager segment, it has a very strong presence in the small ale segment with a 74\% share. On the contrary, the Traditional group has just a tiny share of $2 \%$ of the tiny ale segment.

A remarkable picture revealed by Figure 3 is that the "Craft" and "Import" groups have captured $98 \%$ of the ale segment for 2008! As we have stated earlier, these two groups are aimed primarily at the premiummarket. So, in view of the above information, we are going to restrict cluster analysis only to the lager segment.

\subsection{Hierarchical Clustering as the Primary Instrument of Statistical Analysis}

We have used cluster analysis as the primary statistical instrument in this study. As suggested by Ketchen and Shook (1996), we have taken several steps to make this effort as objective as possible. First, this study is not ad-hoc, but is grounded in a theoretical framework as laid out below. Second, we are fortunate that we were able to get sales data for our study for two years. Thus, this data provided a robust vehicle for subjecting cluster consistency and reliability to an additional test. Third, we wanted to use two different techniques-KMeans and Hierarchical--to add another layer of cluster consistency and reliability. However, we found that the Hierarchical alternative proved to be superior in meeting that test. So, we did not consider it necessary to use the KMeans technique.

\subsection{Theoretical Foundation for Determining Number of Clusters - and their Meaning}

As already stated, a major purpose of this paper is to identify the market share leader in the lager segment and determine the price-quality segment—-based on unit price—it is competing in.

As mentioned before, an important question in performing cluster analysis is determining the number of clusters based on an a priori theory. Most consumer markets can be divided in three basic price-quality segments: premium, mid-price, and economy (Datta, 1996). These three basic segments can be extended to five: with the addition of super-premium and ultra-economy segments.

Therefore, three represents the minimum and five the maximum number of clusters (Datta, 2012).

An equally crucial issue is to figure out what each cluster (e.g., economy, mid-price, and premium) really means.

Perhaps a good way to understand what each price-quality segment stands for in real life is to look at a socio-economic lifestyle profile of America. It reveals six classes. Each class is associated with a price-quality segment typified by the retail stores where they generally shop: each a symbol of their lifestyle (Datta, 2011) (Note 5). 


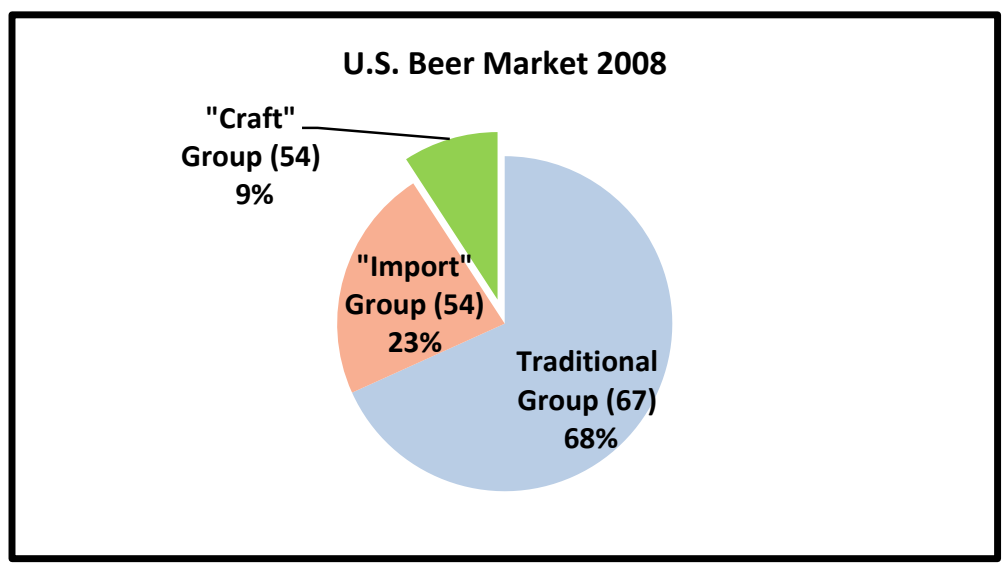

Figure 1. Total Beer Market Share by Major Market Segments

Note. Figures in parenthesis are number of brands with total beer sales $>\$ 1 \mathrm{M}$.

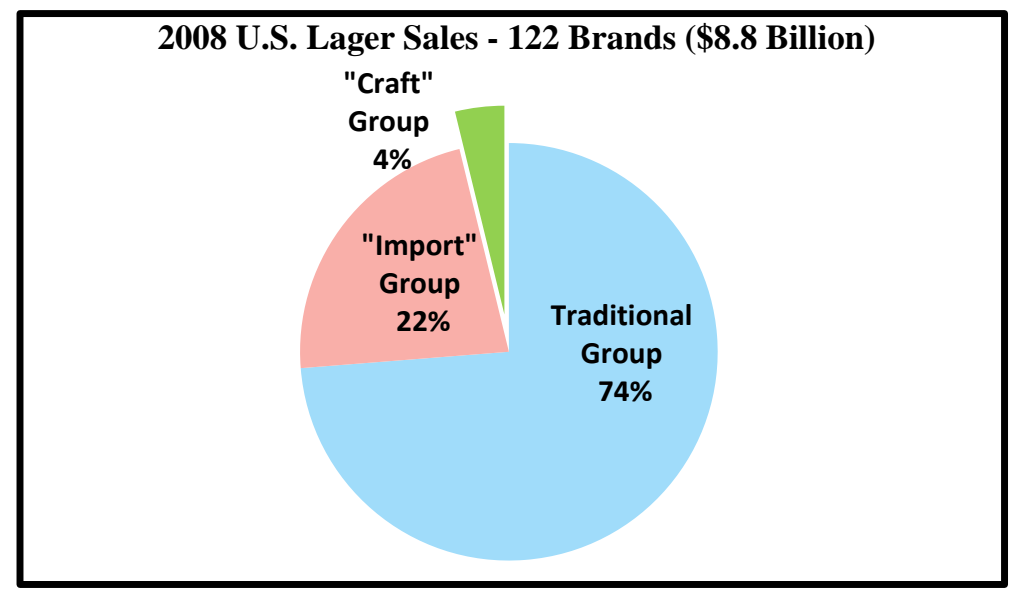

Figure 2. Lager Market Share by Major Market Segments

Note. Figures in parenthesis are number of brands with total beer sales $>\$ 1 \mathrm{M}$.

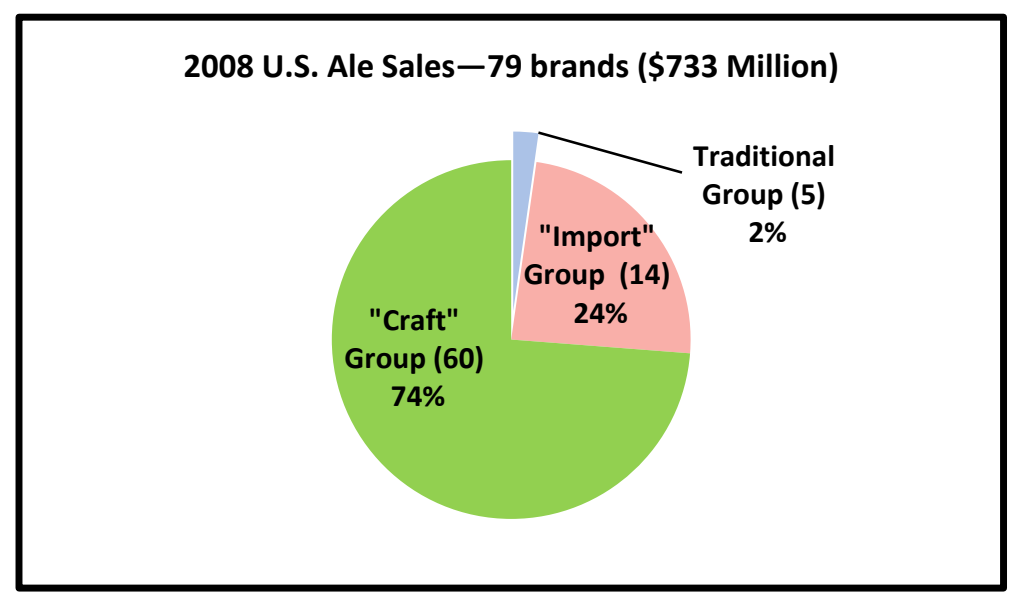

Figure 3. Ale Market Share by Major Market Segments

Note. Figures in parenthesis are number of brands with total beer sales $>\$ 1 \mathrm{M}$. 


\subsection{Guidelines for Cluster Consistency and Reliability}

In addition to laying a theoretical foundation for the number of clusters, we set up the following guidelines to enhance cluster consistency and reliability (Datta, 2012):

- In general, there should be a clean break between contiguous clusters.

- The anchor clusters - the top and the bottom—should be robust. In a cluster-analysis project limited to a range of three to five clusters, a robust cluster is one whose membership remains constant from three- to four- or four- to five-cluster solutions.

- Finally, we followed a step-by-step procedure to determine the optimal solution. First, we start with three clusters. Thus, the bottom cluster obviously becomes the economy segment and the top cluster the premium segment. Next, we go to four clusters, and tentatively call them: economy, mid-price, premium, and super-premium. Then we go to five clusters. If the membership of the bottom cluster remains unchanged from what it was in the four-cluster result, it clearly implies that the ultra-economy segment does not exist. Next, if the membership of the top cluster also remains the same from a four- to a five-cluster answer, then the top cluster becomes the super-premium segment. This means that even in a five-cluster solution we have only four price-quality segments: economy, mid-price, premium, and super-premium. It means that either the premium or the mid-price segment consists of two sub-segments (e.g., see Table 1).

\subsection{Cluster Analysis Restricted to the Lager Segment}

We have confined cluster analysis to the enormous lager segment which captured $92 \%$ of the total beer market for 2008. The reason for this is that, unlike lager, which ran the gamut of super-premium to economy segments, the ale market was geared heavily towards the upper end-mainly the premium segment.

Since beer comes in several package combinations, we wanted to focus on the largest two, to bolster the validity and reliability of the results of cluster analysis. The first choice clearly was the 12-pack which was by far the most popular with 33\% share. Next, we had four options closely bunched together: 24-pack, 18-pack, 6-pack, and 30-pack. We chose the 6-pack with $13 \%$ share because many small brewers did not even offer the 12-pack.

\subsection{Hypotheses I and II}

- I-That the market-share leader would be a member of the mid-price segment, and

- II-That the market-share leader would carry a price tag that is higher than that of the nearest competition. 
Table 1. U.S. Lager Market 12-pack 2008: Hierarchical Cluster Analysis (94 cases)

\begin{tabular}{|c|c|c|c|c|}
\hline Price-Quality Segment & Brand Name & ClusCtr & Uprice & MktShare (Note 6) \\
\hline \multirow[t]{2}{*}{ Super Premium: Cluster 1} & ANCHOR STEAM & $\$ 16.10$ & $\$ 16.21$ & $0.0 \%$ \\
\hline & FLYING DOG ASSORTED & & $\$ 15.98$ & $0.0 \%$ \\
\hline \multirow[t]{32}{*}{ Premium: Cluster 2} & KONA BREWING CO. & $\$ 13.29$ & $\$ 14.96$ & $0.1 \%$ \\
\hline & SPATEN MALT LIQUOR & & $\$ 14.93$ & $0.1 \%$ \\
\hline & STELLA ARTOIS LAGER & & $\$ 14.86$ & $0.5 \%$ \\
\hline & GREAT LAKES DORTM & & $\$ 14.41$ & $0.0 \%$ \\
\hline & PERONI NASTRO AZZURRO & & $\$ 14.35$ & $0.1 \%$ \\
\hline & SIERRA NEVADA SUMFEST & & $\$ 14.15$ & $0.1 \%$ \\
\hline & PILSNER URQUELL & & $\$ 14.10$ & $0.1 \%$ \\
\hline & ABITA AMBER & & $\$ 14.00$ & $0.0 \%$ \\
\hline & NEGRA MODELO DARK & & $\$ 13.83$ & $0.2 \%$ \\
\hline & LANDSHARK & & $\$ 13.80$ & $0.2 \%$ \\
\hline & AMSTEL LIGHT & & $\$ 13.79$ & $0.4 \%$ \\
\hline & PYRAMID SEASONAL & & $\$ 13.76$ & $0.0 \%$ \\
\hline & CORONA & & $\$ 13.59$ & $6.3 \%$ \\
\hline & BOHEMIA & & $\$ 13.58$ & $0.0 \%$ \\
\hline & HEINEKEN & & $\$ 13.56$ & $4.0 \%$ \\
\hline & SAMUEL ADAMS LAGER & & $\$ 13.56$ & $1.3 \%$ \\
\hline & CARLSBERG & & $\$ 13.49$ & $0.0 \%$ \\
\hline & DOS EQUIS SPECIAL LAGER & & $\$ 13.28$ & $0.6 \%$ \\
\hline & SAPPORO & & $\$ 13.19$ & $0.1 \%$ \\
\hline & RED STRIPE & & $\$ 13.10$ & $0.3 \%$ \\
\hline & PACIFICO & & $\$ 13.06$ & $0.4 \%$ \\
\hline & GORDON BIERSCH MARZEN & & $\$ 13.02$ & $0.0 \%$ \\
\hline & BECK'S & & $\$ 13.00$ & $0.7 \%$ \\
\hline & HARP & & $\$ 12.86$ & $0.1 \%$ \\
\hline & WARSTEINER PRM. VERUM & & $\$ 12.68$ & $0.1 \%$ \\
\hline & SOL & & $\$ 12.65$ & $0.1 \%$ \\
\hline & MODELO ESPECIAL & & $\$ 12.65$ & $0.8 \%$ \\
\hline & SARANAC $12 \mathrm{~S}$ OF XMS & & $\$ 12.45$ & $0.0 \%$ \\
\hline & LOWENBRAU & & $\$ 12.34$ & $0.0 \%$ \\
\hline & HOLLANDE 1620 & & $\$ 12.23$ & $0.0 \%$ \\
\hline & GROLSCH & & $\$ 12.16$ & $0.1 \%$ \\
\hline & SHINER BOCK & & $\$ 12.02$ & $0.3 \%$ \\
\hline
\end{tabular}




\begin{tabular}{|c|c|c|c|c|}
\hline & TSINGTAO & & $\$ 12.00$ & $0.0 \%$ \\
\hline & STEINLAGER & & $\$ 11.94$ & $0.0 \%$ \\
\hline & TYSKIE GRONIE LAGER & & $\$ 11.81$ & $0.0 \%$ \\
\hline \multirow[t]{28}{*}{ Mid-Price I: Cluster 3} & BAVARIA & $\$ 10.45$ & $\$ 11.62$ & $0.0 \%$ \\
\hline & ST PAULI GIRL & & $\$ 11.51$ & $0.3 \%$ \\
\hline & ZIEGENBOCK AMBER & & $\$ 11.46$ & $0.0 \%$ \\
\hline & KIRIN ICHIBAN & & $\$ 11.41$ & $0.0 \%$ \\
\hline & LEINENKUGEL'S SEASONAL & & $\$ 11.33$ & $0.3 \%$ \\
\hline & SESSION & & $\$ 11.20$ & $0.0 \%$ \\
\hline & HOLLANDIA AMBER LAGER & & $\$ 11.18$ & $0.0 \%$ \\
\hline & FOSTER'S & & $\$ 11.17$ & $0.3 \%$ \\
\hline & PRESIDENTE & & $\$ 10.92$ & $0.1 \%$ \\
\hline & GEORGE KILLIAN'S IRISH & & $\$ 10.88$ & $0.3 \%$ \\
\hline & MOOSEHEAD & & $\$ 10.74$ & $0.1 \%$ \\
\hline & DUNDEE HONEY BROWN & & $\$ 10.47$ & $0.1 \%$ \\
\hline & MICKEYS MALT LIQUOR & & $\$ 10.28$ & $0.2 \%$ \\
\hline & MICHELOB ULTRA LIGHT & & $\$ 10.45$ & $4.0 \%$ \\
\hline & ROLLING ROCK & & $\$ 10.25$ & $0.4 \%$ \\
\hline & TECATE & & $\$ 10.24$ & $1.2 \%$ \\
\hline & HENRY WEINHARD'S PriRerve & & $\$ 10.23$ & $0.1 \%$ \\
\hline & ROCK GREEN LIGHT & & $\$ 10.11$ & $0.1 \%$ \\
\hline & MOLSON CANADIAN & & $\$ 10.03$ & $0.3 \%$ \\
\hline & KOKANEE GLACIER & & $\$ 9.99$ & $0.1 \%$ \\
\hline & CAGUAMA & & $\$ 9.97$ & $0.1 \%$ \\
\hline & COORS LIGHT & & $\$ 9.84$ & $8.3 \%$ \\
\hline & LABATT BLUE PILSNER & & $\$ 9.63$ & $0.9 \%$ \\
\hline & BUD LIGHT & & $\$ 9.61$ & $17.9 \%$ \\
\hline & CARTA BLANCA & & $\$ 9.60$ & $0.0 \%$ \\
\hline & YUENGLING AMBER LAGER & & $\$ 9.59$ & $0.6 \%$ \\
\hline & BUDWEISER & & $\$ 9.59$ & $8.7 \%$ \\
\hline & MILLER LIGHT & & $\$ 9.31$ & $12.8 \%$ \\
\hline \multirow[t]{5}{*}{ Mid-Price II: Cluster 4} & O'DOUL'S NEAR Beer & $\$ 8.62$ & $\$ 9.09$ & $0.5 \%$ \\
\hline & POINT SPECIAL LAGER & & $\$ 8.95$ & $0.0 \%$ \\
\hline & POLAR & & $\$ 8.59$ & $0.0 \%$ \\
\hline & RAINIER & & $\$ 8.54$ & $0.0 \%$ \\
\hline & LONE STAR & & $\$ 7.96$ & $0.1 \%$ \\
\hline
\end{tabular}




\begin{tabular}{|c|c|c|c|c|}
\hline \multirow[t]{24}{*}{ Economy: Cluster 5} & SHARP'S NEAR Beer & $\$ 6.58$ & $\$ 7.43$ & $0.1 \%$ \\
\hline & ICEHOUSE & & $\$ 7.33$ & $0.6 \%$ \\
\hline & OLD STYLE & & $\$ 7.21$ & $0.2 \%$ \\
\hline & RED DOG & & $\$ 7.16$ & $0.1 \%$ \\
\hline & BUSCH LIGHT & & $\$ 6.98$ & $4.7 \%$ \\
\hline & OLYMPIA & & $\$ 6.96$ & $0.0 \%$ \\
\hline & PABST BLUE RIBBON & & $\$ 6.90$ & $0.7 \%$ \\
\hline & STAG & & $\$ 6.68$ & $0.0 \%$ \\
\hline & KEYSTONE LIGHT & & $\$ 6.67$ & $1.6 \%$ \\
\hline & SOUTHPAW LIGHT & & $\$ 6.66$ & $0.0 \%$ \\
\hline & NATURAL LIGHT & & $\$ 6.64$ & $4.3 \%$ \\
\hline & GENESEE & & $\$ 6.62$ & $0.1 \%$ \\
\hline & SCHLITZ & & $\$ 6.56$ & $0.1 \%$ \\
\hline & STEEL RESERVE HIGH GRVY & & $\$ 6.53$ & $0.3 \%$ \\
\hline & GENNY LIGHT & & $\$ 6.51$ & $0.1 \%$ \\
\hline & STROH'S & & $\$ 6.44$ & $0.0 \%$ \\
\hline & HAMM'S & & $\$ 6.44$ & $0.1 \%$ \\
\hline & OLD MILWAUKEE & & $\$ 6.34$ & $0.5 \%$ \\
\hline & COLT 45 MALT LIQUOR & & $\$ 6.33$ & $0.1 \%$ \\
\hline & HURRICANE HIGH GRVTY & & $\$ 6.15$ & $0.1 \%$ \\
\hline & MILWAUKEE'S BEST LIGHT & & $\$ 6.10$ & $2.1 \%$ \\
\hline & SCHAEFER & & $\$ 5.87$ & $0.0 \%$ \\
\hline & GOYA NEAR & & $\$ 5.69$ & $0.1 \%$ \\
\hline & BLATZ & & $\$ 5.58$ & $0.0 \%$ \\
\hline
\end{tabular}

Total Lager Market Share (94 brands) $=91 \%$.

\section{Results of Cluster Analysis of the Lager Segment}

7.1 The 12-Pack (Note 7) Lager Segment 2008

To keep the number of brands to a manageable size, we did not consider those with total beer sales of less than \$1million. Another problem was that almost every brand offered multiple styles often at different prices. So, we decided that the best solution was to choose the top-selling style for each pack as the most appropriate measure of a brand's comparative unit price.

Following the guidelines outlined above, the results of Hierarchical cluster analysis that features 94 brands, are presented in Table 1 which shows five clusters. However, it has only four price-quality segments, with the mid-price segment containing two sub-segments.

The market share refers to the beer (lager and ale) market share of brands with sales over $\$ 1 \mathrm{M}$ that accounted for $99 \%$ of total 2008 beer sales.

Bud Light is the run-away leader with $17.9 \%$ of total beer sales, followed by Miller Light with $12.8 \%$. 
And both are members of the mid-price segment. More importantly, Bud Light's unit price is $\$ 9.61$, slightly higher than the $\$ 9.31$ of Miller Light.

So, clearly, the above results provide strong support for both Hypothesis I and II.

Finally, the results of Table 1 provide the following interesting insights:

- Both members of the super-premium segment are the craft brands.

- The premium segment is populated by the "Import" group (71\%), and the "Craft" group (29\%), with Corona Extra (6.3\%) and Heineken (4\%) holding the top two spots.

- In the mid-price I sub-segment, the number three and four - part of what we can call the "Big Four"- positions are occupied by Budweiser (8.7\%) and Coors (8.3\%).

- In the economy segment the two largest brands are Busch Light and Natural Night, both part of the AB-InBev family, with respective market shares of $4.7 \%$ and $4.3 \%$.

Table 1 reveals another piece of information that deserves attention. We had reported earlier that A-B had reintroduced Michelob as the first national premium brand in 1966. But, fierce competition from the imports and craft brands has pushed Michelob down to the mid-price segment.

We performed similar analyses for 12-pack 2007, and 6-pack 2008 and 2007. Like the 12-pack 2008, the results of these three analyses, too, equally supported both hypotheses.

To sum up: Following the above discussion, it is clear that the results of cluster analysis for the lager

12-pack segment-as well as the 6-pack-have provided an overwhelming evidence in support of Hypothesis I and II, not only for 2008 but for 2007 as well!

The above results provide a dramatic affirmation of the idea, as we have stated earlier, that the American mass market of yesterday has now become a class market of today!

\section{Relative Price a Strategic Variable}

Finally, we performed one more test to determine the consistency and reliability of the results of cluster analysis in this study. First, we ranked the unit price of each brand—both for 2008 and 2007, and also for 12-packs and 6-packs.

Surprisingly, in all four cases and all three measures of bivariate correlation-Pearson, and non-parametric measures Kendall's tau_b, and Spearman's rho_-were found to be significant at an amazing 0.01 level!

We believe these surprising results - that cover such a large number of brands - became possible only because management in the U.S. Beer market must have been treating price as a strategic variable, as we have suggested.

While the price of a brand, compared to its nearest competition, may change over time, it is unlikely to differ much from one year to the next. This is vital not only for the market share leader, but also for every brand no matter which price-quality segment it is competing in.

Another conclusion one can draw from such unbelievable results is that the U.S. beer market is highly 
competitive.

\subsection{Large Companies Rely on Heavy Promotion}

For both 2008 and 2007, we performed bivariate correlation for lager between Total (net) Sales vs. Promotion (PROMO) Sales for 2,716 SKUs. The results were significant for all three measures-Pearson, Kendall, and Spearman —at the 0.01 level for both 2008 and 2007.

Similarly, the results were equally significant for the 2418 ale SKUs.

Next we wanted to determine to what extent the results of the above analyses were consistent between 2008 vs. 2007. So, we calculated 12-pack lager PROMO sales as a percentage of total sales for 94 brands; and 96 ale 6-packs. But, instead of performing correlation analysis on this cardinal data, we chose instead a weaker cousin: by converting it into an ordinal rank data.

To our surprise, all three correlations even for this ordinal data were found to be significant at the 0.01 level for lager as well as ale. This confirms the notion that the promotion policies in the U.S. beer market did not change much between 2008 and 2007.

Another implication of the above results is that, in general, high market-share brands relied far more on promotion than those with market share at the lower end.

We present Table 2 to see which brands were the leading users of promotion.

Table 2 includes 33 brands with 2008 lager sales over $\$ 25$ million. These brands encompass $94 \%$ of the 2008 lager market. We have divided the table into three parts representing brands that fell into the premium, mid-price and economy segments, as per the results of 2008 cluster analysis for the 12-pack. Within each segment, we have placed brands by percentage of promotion sales to total sales in a descending order.

We found that the large brands relied heavily on promotion. On average, promotional sales averaged $48 \%$ of total lager sales; the corresponding figures for the premium, mid-price, and economy segments were $54 \%, 50 \%$, and $33 \%$, respectively,

The premium group is dominated by the "Import" segment with 8 out of 10 , followed by 2 in the "Craft" group. The highest score in this segment is owned by Corona at 59\%. This is perhaps one reason Corona became the best-selling import in America.

The most dominant brands in the mid-price segment are the "The Big Four"-Bud Light, Miller Light, Budweiser, and Coors Light. Their respective scores are: $54 \%, 52 \%, 51 \%$, and $52 \%$. It is remarkable how unbelievably close these numbers are.

It seems the managements of $\mathrm{AB}-\mathrm{In}-\mathrm{Bev}$ and Molson Coors must have been reading from the same script!

We suggest that the "Import" group relied on heavy promotion to support their premium prices. On the other hand, the traditional mid-price group - typified by the "Big Four"-employed heavy promotion because their economies of scale made it economically feasible. Finally, since the economy group was competing on lower prices to begin with, it did not need the additional weapon of deep discounts.

The large promotional footprint we have just seen is still another indication that the U.S. beer market 
was very competitive in 2008 , and is unlikely to have changed much since then.

\section{Anatomy of the U.S. Beer Market}

\subsection{Why Craft Brewers favor Ale over Lager?}

As we mentioned before, ales are produced with top-fermenting yeast at warm temperatures between $65^{\circ}$ and $73^{\circ} \mathrm{F}$. At warm temperatures yeast generates a lot more of the fruity aroma molecules known as esters, and other chemicals, that add spicy, fruity character to beer.

A major reason why craft brewers mostly produce ales is because craft beer drinkers strongly prefer ales. They are attracted to ale because it offers "more flavor, intensity, and diversity..." (italics added) $\begin{array}{lllll}\text { (Aubrey } & \text { Laurence. } & \text { Retrieved } & \text { November } & \text { 20, 2017, from }\end{array}$ http://www.taptrail.com/why-theres-a-lack-of-love-for-craft-lagers/).

Ale recipes often have a higher amount of hops, malt and roasted malts, so they project a more prominent malty taste and bitterness. Another argument in their favor is that they have more room for experimentation (Beer Tutor. Retrieved November 21, 2017, from http://www.beertutor.com/articles/ales_vs_lagers.shtml).

Nevertheless - even given their preference for ale - a large majority of craft brewers, except for Samuel Adams and Yuengling, do not like to brew lagers. Laurence offers three reasons:

- Lagers require much more time to make than ales, which results in lower capacity, and lower profit.

- Lagers are far more challenging to make than ales. Due to their cleaner and more delicate character, any flaws are likely to be noticeable. On the contrary, ales are much better at masking "off flavors, poor attenuation, infections and other flaws with bold doses of hops, highly roasted malts, yeast esters, etc. (ibid).

- Because ales are fermented at warm temperatures, brewing lager at cold temperatures "between $30 \mathrm{~F}$ and $31 \mathrm{~F}$ can be outside the capabilities of brewers that are set up mainly to brew ale" (ibid).

\subsection{Lager Style Profile}

Perhaps nothing is more important about popularity of beer than its color. And the color that dominates the beer world is pale - or pilsner (Mosher, 2009, p. 3). One can see no better demonstration of this reality than the picture painted by Figure 4 .

It shows that in 2008 pale lager sales were a staggering $93 \%$ of total lager sales; of this a monumental 55\% were accounted for by American Adjunct light lager, while American Adjunct regular lager took a $31 \%$ share, adding up to $86 \%$ share for the entire Adjunct group. 
Table 2. Promo Sales as a Percentage of Total Lager Sales

\begin{tabular}{|c|c|c|c|}
\hline 33 Brands with 2008 Lager Sales $>\$ 25 M$ & Sales2008 \$M & MkShLager & \%PromoSales \\
\hline \multicolumn{4}{|l|}{ Premium Segment } \\
\hline Corona Beer & $\$ 598$ & $6.8 \%$ & $\mathbf{5 9 \%}$ \\
\hline Heineken Beer & $\$ 382$ & $4.3 \%$ & $51 \%$ \\
\hline Samuel Adams Beer & $\$ 127$ & $1.4 \%$ & $51 \%$ \\
\hline Modelo Beer & $\$ 75$ & $0.9 \%$ & $45 \%$ \\
\hline Beck's Beer & $\$ 66$ & $0.8 \%$ & $41 \%$ \\
\hline Dos Equis Beer & $\$ 55$ & $0.6 \%$ & $49 \%$ \\
\hline Stella Artois Beer & $\$ 50$ & $0.6 \%$ & $46 \%$ \\
\hline Pacifico Beer & $\$ 43$ & $0.5 \%$ & $54 \%$ \\
\hline Amstel Beer & $\$ 38$ & $0.4 \%$ & $50 \%$ \\
\hline Shiner Beer & $\$ 28$ & $0.3 \%$ & $48 \%$ \\
\hline Average Premium segment score & & $16.6 \%$ & $\underline{\mathbf{5 3 \%}}$ \\
\hline \multicolumn{4}{|l|}{ Mid-Price Segment } \\
\hline Bud Light Beer & $\$ 1,701$ & $19.4 \%$ & $54 \%$ \\
\hline Miller Light Beer & $\$ 1,221$ & $13.9 \%$ & $52 \%$ \\
\hline Budweiser Beer & $\$ 831$ & $9.5 \%$ & $51 \%$ \\
\hline Coors Light Beer & $\$ 789$ & $9.0 \%$ & $52 \%$ \\
\hline Michelob Beer & $\$ 377$ & $4.3 \%$ & $34 \%$ \\
\hline Tecate Beer & $\$ 116$ & $1.3 \%$ & $61 \%$ \\
\hline Labatt Beer & $\$ 84$ & $1.0 \%$ & $47 \%$ \\
\hline 33 Brands with 2008 Lager Sales $>\$ 25 M$ & Sales2008 \$M & MkShLager & \%PromoSales \\
\hline O’Doul's Beer & $\$ 44$ & $0.5 \%$ & $16 \%$ \\
\hline Foster's Beer & $\$ 31$ & $0.4 \%$ & $25 \%$ \\
\hline St Pauli Girl & $\$ 31$ & $0.4 \%$ & $39 \%$ \\
\hline Molson Beer & $\$ 28$ & $0.3 \%$ & $28 \%$ \\
\hline George Killian’s Beer & $\$ 28$ & $0.3 \%$ & $32 \%$ \\
\hline Leinenkugel's Beer & $\$ 25$ & $0.3 \%$ & $37 \%$ \\
\hline Average Mid-Price segment score & & $42.1 \%$ & $\underline{\mathbf{5 0 \%}}$ \\
\hline \multicolumn{4}{|l|}{ Economy Segment } \\
\hline Busch Beer & $\$ 443$ & $5.0 \%$ & $38 \%$ \\
\hline Natural Beer & $\$ 409$ & $4.7 \%$ & $32 \%$ \\
\hline Milwaukee Beer & $\$ 196$ & $2.2 \%$ & $27 \%$ \\
\hline Keystone Beer & $\$ 155$ & $1.8 \%$ & $41 \%$ \\
\hline Pabst Beer & $\$ 65$ & $0.7 \%$ & $32 \%$ \\
\hline
\end{tabular}




\begin{tabular}{llll}
\hline Icehouse Beer & $\$ 61$ & $0.7 \%$ & $17 \%$ \\
Old Milwaukee Beer & $\$ 50$ & $0.6 \%$ & $25 \%$ \\
Steel Reserve Beer & $\$ 33$ & $0.4 \%$ & $9 \%$ \\
Average Economy segment score & & $\mathbf{1 6 . 1 \%}$ & $\underline{\mathbf{3 3 \%}}$ \\
Total Sales/Overall Av. Promo score & $\mathbf{\$ 8 , 2 7 5}$ & $\mathbf{9 4 . 2 \%}$ & $\underline{\mathbf{4 8 \%}}$ \\
Total 2008 Lager Sales & $\mathbf{\$ 8 , 7 8 4}$ & $\mathbf{1 0 0 . 0 \%}$ & \\
\hline
\end{tabular}

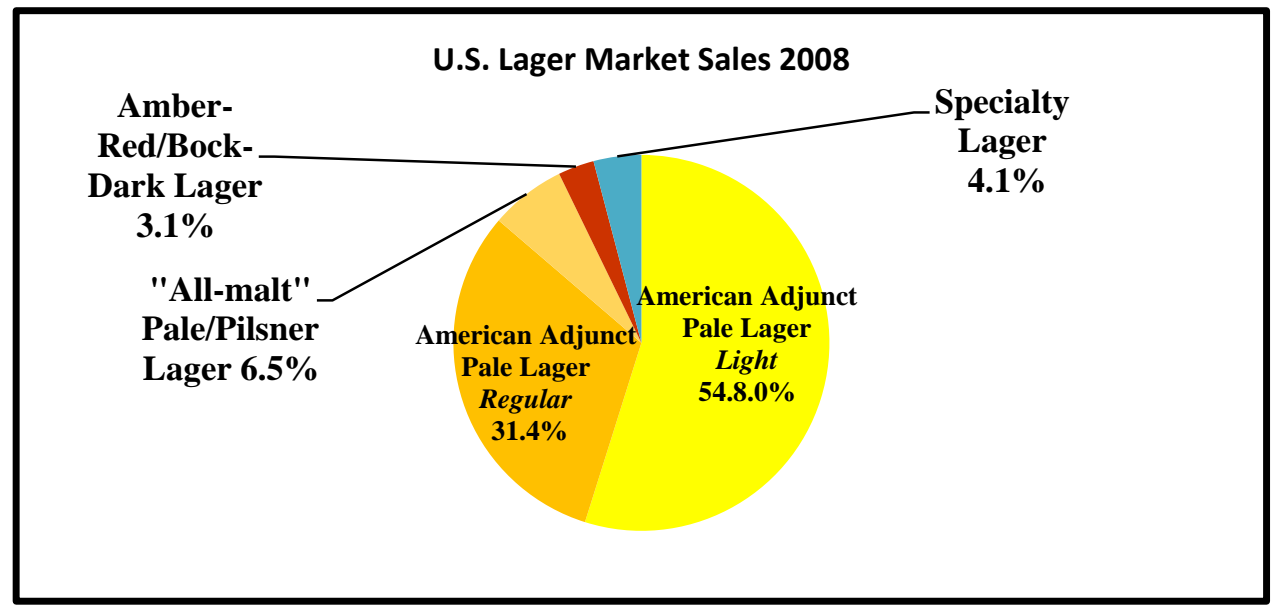

Figure 4. Percentage of Major Lager Style Groups

"All-malt" pale lagers—pilsners as they call them in Europe-recorded $6.5 \%$ of the lager market in 2008. The largest segment in this group was Euro Pale Lager with $4.5 \%$ share, of which Heineken was the most dominant with $80 \%$ share. The next in line was Germen Pilsner with $1 \%$ share, with Beck's owning a little more than a half.

The Amber-Red/Bock-Dark group was able to muster only 3.1\% share with Amber-Red style by far the largest. The top seller of this style was Yuengling with over 40\% share. In the Bock style Michelob had about one-half share. Finally, in the Dark group the largest seller was Negra Modelo's Munich Dunkel lager which had close to a $70 \%$ share.

The Specialty Group, which includes many styles, shows a $4.1 \%$ share. One style is Non-alcohol or Near-Beer with 1\% share. Of this, O'Doul's — part of AB-InBev family—had half.

9.3 Light Lagers vs. Regular Lagers: What's the Difference?

As Figure 4 above shows, light lager sales were 55\% of total lager sales in 2008.

There are two conflicting views about this problem.

According to Beer Advocate, while light beers have a lower content, "they have the least amount of flavor that any other style of beer (Retrieved November 25, 2017, from https://www.beeradvocate.com/beer/style/39/).

On the other hand, Anheuser Busch's brewmaster, Travis Moore, has an entirely opposite perspective.

He says "[1]ight style beers are just as much 'regular' beer as styles that feature a fuller body profile". 
What makes a beer light is that it is lower in calories — and as a result—lower in alcohol. As the famous Miller Lite ad said, it "tastes great", but is "less filling" (Pomranz, 2017).

Jim Koch of Boston Beer Co., maker of Samuel Adams, points out that making light beer requires more time and attention. He says it involves kilning the malt at high temperature to kill malt enzymes which then lower the amount of fermentable sugars, which, in turn, results in both lower calories and lower alcohol at the same time (ibid).

Moore says that light beer of a company does not stand by itself, but as a counterpart to another with higher calories (e.g., Bud Light vs. Budweiser). He suggests light beers are more difficult to make consistently with high quality because they can be "extremely unforgiving due to their lighter body and more subtle flavor profile" ( ibid; italics added).

But why are craft brewers generally not interested in making light beer? Moore suggests that light beer is appropriate for large companies. First, large-scale operation allows a macro player to produce high-quality malt in-house. Second, time and money are other factors, and up-front equipment cost can be prohibitive. Third, the "unforgiving process takes years of study and experience to master" (ibid).

Finally, Koch says that craft brewers and drinkers "aren't thinking of calorie count, they're thinking of flavor. A brewer won't compromise his or her art to cut a few calories from a masterpiece" (ibid).

\subsection{American Malt Liquor: Largely Targeted at Poor Youth}

One beer style that deserves special attention is American Malt Liquor (AML) which had a little more than $1 \%$ share in 2008. It is known for its high alcohol volume. There are many players in this field, with Steel Reserve - part of Molson Coors - the clear leader. Others are Molson and Coors' Mickey's, Olde English, and Magnum; AB-InBev's King Cobra and Hurricane; and Pabst group's Colt 45 and Schlitz.

This is what Beer Advocate (2017) has said about AML:

For the most part, Malt Liquor bottles are sold in the infamous 40-oz sized bottles...[Most] use excessive amount of adjuncts such as corn, rice, refined brewers sugar...Hops are barely used...Some breweries enable the use of special enzymes to further breakdown the malt and adjuncts so they will yield a larger percentage of alcohol. This makes for quite a dry beer, with only a small amount of unfermented sugars and a kick that will knock you on your ass.

The 2008 sales data confirms Beer Advocate's observation that, typically, AML is being sold in large bottles. We found that more than $50 \%$ of this style was sold in bottles over $24 \mathrm{oz}$ : $30 \%$ in $24 \mathrm{oz}, 18 \%$ in $40 \mathrm{oz}$, and $6 \%$ in $32 \mathrm{oz}$.

Most Light lagers have ABV (average by volume) of 4.2\%, while popular regular beers like Budweiser have an $\mathrm{ABV}$ of $5 \%$. However, the ABV of AML ranges from 6 to as high as 10\%! (Beer Advocate. Retrieved November 16, 2017, from https://www.beeradvocate.com/beer/style/42/).

Another interesting nugget that emerges from the 2008 data is that promotional sales of AML were just 9\% vs. $48 \%$ for lager as a whole. This seems to imply that AML drinkers are loyal customers who do not have to be enticed by heavy promotion to get themselves drunk!

Published by SCHOLINK INC. 
Critics argue that the "Forties" (as the 40-oz bottles are called) are targeted largely at the urban poor African American and Latino youth in search of a "cheap high". They are usually sold "chilled and wrapped in a brown paper bag for immediate consumption". AML makers have consciously come up with creative brand names like Magnum, Hurricane, King Cobra, and Steel Reserve to "connote power and machismo" (Marriot, 1993; Science News, 2005).

As a result, poor teen-agers are increasingly becoming alcoholics, and many see the "Forties" as an alternative to drugs, and some call them as "liquid crack" (ibid).

\subsection{Role of Ultra-Deep Discounts in Popularity of Large Packs}

The lager pack sizes for 2008 fell into three main groups: 12-pack, six-pack, and larger sizes-18-pack and higher-with $33 \%, 13 \%$, and $41 \%$ shares, respectively.

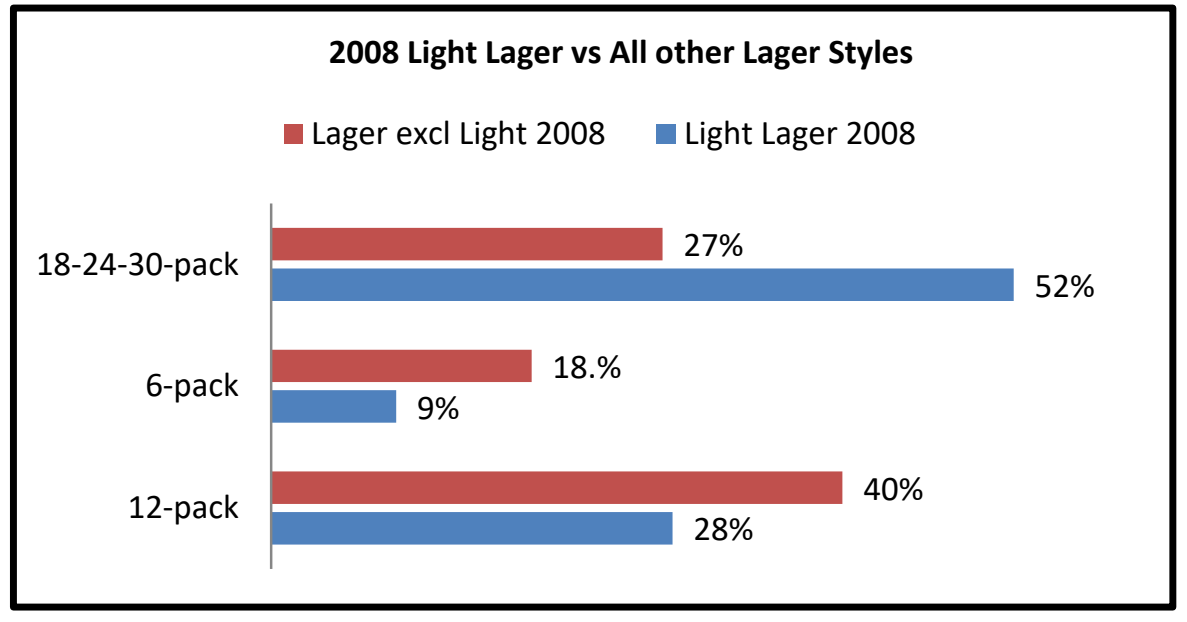

Figure 5. Percentages of Major Package Sizes 2008

As Figure 4 shows, sales of light lager alone were 55\% in 2008. So, we thought it would be more revealing to have two sets of figures: one for light lager and another for every other style combined. Figure 5 is the result of this effort.

And lo and behold, the two groups project a dramatically different picture! It shows that more than half of light lager was sold in large packages, but sales of the small six-pack were a mere 9\%.

So, what is behind the extraordinarily high large-pack sales? Obviously, the answer is not simple. Nevertheless, the overriding explanation for this riddle is provided by the promotional sales data shown in Figure 6.

Instead of examining all light lager brands, we looked at just the "Big Three": Bud Light, Miller Light, and Coors Light (Figure 6). Together they held more than 70\% of light lager market in 2008.

As the following discussion shows, the picture presented by Figure 6 is even more radical than that of Figure 5!

- Except for the 6-pack, the figures for the three brands are remarkably close to each other. 
- For the large 18-24-30-pack segment all three brands show a similar discount pattern: an unbelievable figure close to $70 \%$ ! No wonder, sales of the big packs have gone through the roof.

Arndorfer offers several reasons for multiple pack offerings: customer preference for bottle or can, price point (economy, mid-price, or premium), and consumption occasion. While one might buy a 24-pack for a large party, a 6- or 12-pack may be more appropriate for a smaller one (Miller Coors. Retrieved from http://www.millercoorsblog.com/news/beer-pack-sizes/).

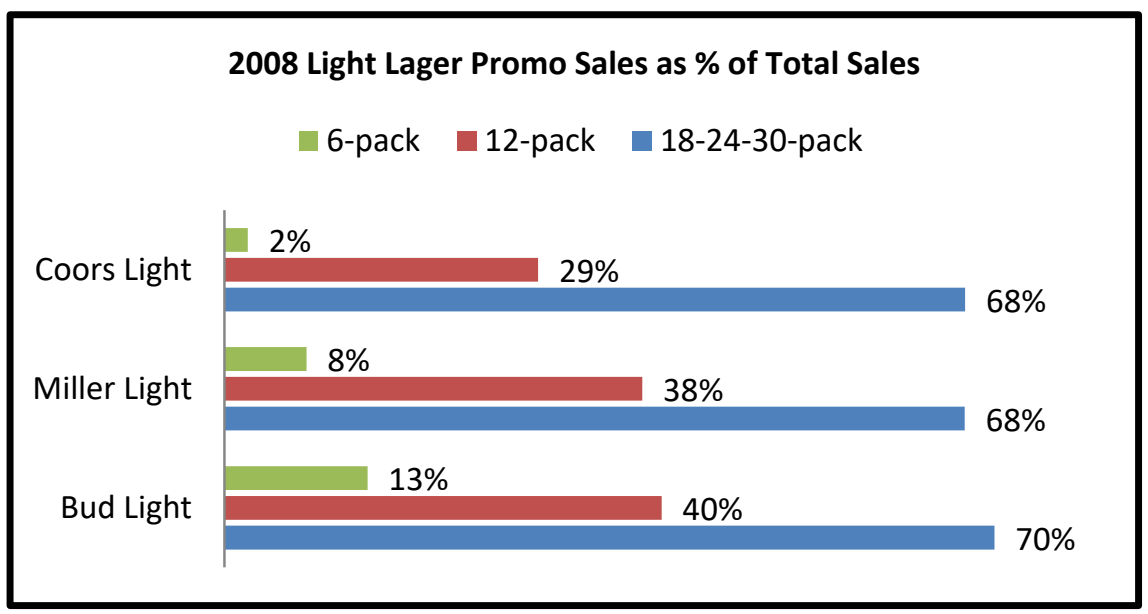

Figure 6. Percentage by Major Lager Pack Sizes

\subsection{Most Popular Ale Packs}

Figure 7 projects the most popular pack sizes for ale in 2008. It presents a picture that is - not unexpectedly - considerably different from a comparative scenario for lager beer-both light and regular.

The 6-pack and 12-pack lager had shares of $13 \%$ and $33 \%$, respectively, of total lager sales. But, as Figure 7 shows, the share of the 6-pack ale was more than half of 2008 ale sales; but the $32 \%$ share of the 12-pack ale is identical to its lager counterpart.

There are three reasons for this disparity. One - and most important—craft beer is mostly sold at premium prices that many customers cannot afford, whereas the most popular lager beers fall in the mid-price or economy segments. Second, craft beer lovers drink beer primarily for flavor. But most of this kind of beer is full-bodied, so one cannot drink too much of it in one sitting. Third, a very large number of craft brands are quite small. So they can offer only a limited selection of pack sizes. Out of 45 craft brands, 17 offered only the smallest six-pack. 


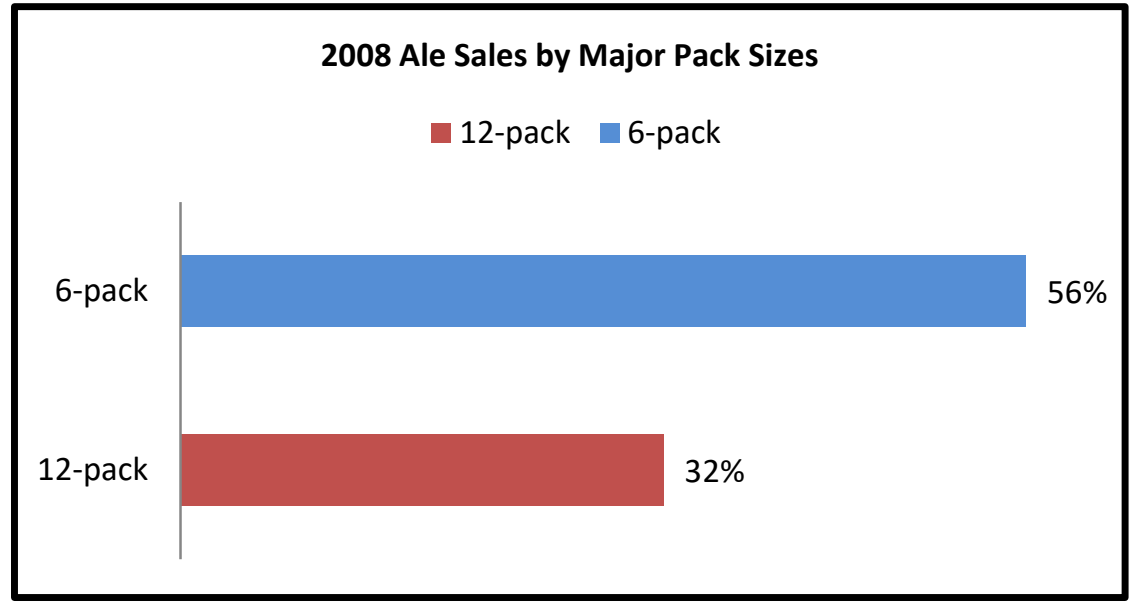

Figure 7. Percentage by Major Ale Pack Sizes

\section{Strategic Groups in the U.S. Beer Market}

We have discovered five strategic groups in the industry as shown in Figure 8 (for an understanding of the concept of strategic groups, see Datta, 2010b).

\subsection{Anheuser Busch In-Bev: Market Leader}

In 2008 IN-Bev, a Belgian company was able to acquire Anheuser Busch. After merger with SAB Miller in 2015, AB-In-Bev has now become a mammoth global company.

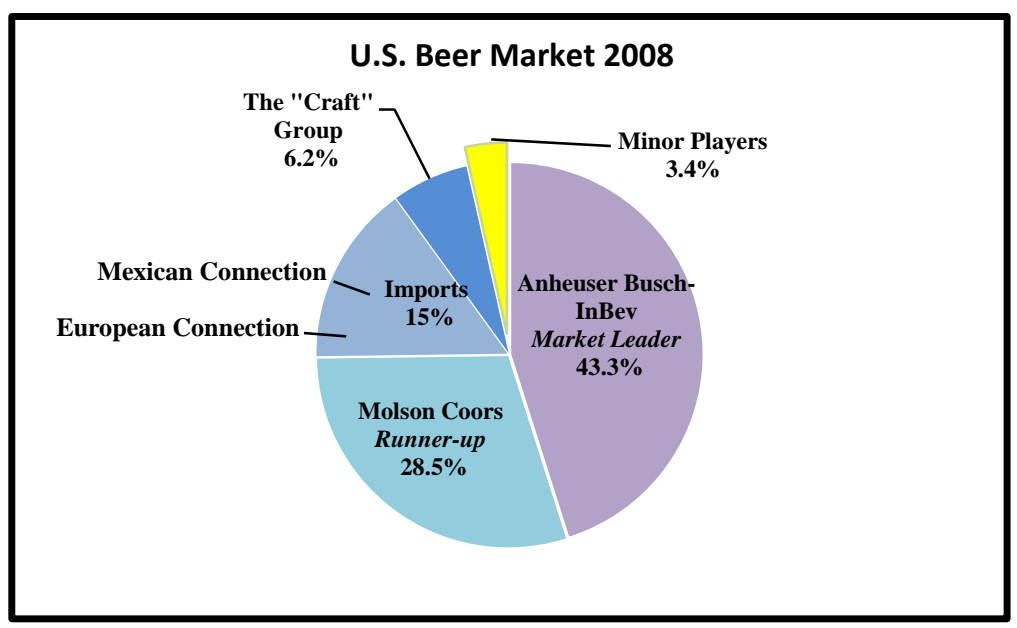

Figure 8. Market Share by Strategic Groups

Now let us go back to 1876, when Adolphus Busch's entrepreneurship created Budweiser, the first American Adjunct lager. The beer was so successful that it changed the face of American brewing forever, and did so almost immediately!

In 2008, AB-In-Bev had a commanding $43 \%$ share of the U.S. beer market (Figure 8).

Realizing the growth potential of imports and craft beer, AB-InBev has acquired several European beers like Stella Artois, St. Pauli girl, and German beer Beck's which is now brewed in America. 
The company has also procured many former craft brands, e.g., Landshark and Goose Island. In addition it has launched home-grown craft beer, Shock Top ale.

In $200875 \%$ of AB-InBev's beer sales were provided by brands in the mid-price segment.

In the 1970s Schlitz had become a darling of Wall Street. Due to its cost leadership strategy it was able to produce a return on equity of $21 \%$ - far more than the $13 \%$ of Anheuser Busch (AB). So Wall Street was pressuring $\mathrm{AB}$ to stop insisting on traditional methods and become more modern. But Gussie, A-B's CEO, stuck to his guns and said where quality is concerned there can be no compromise. As history tells us how right he was!

At the beginning of this century, "half the beer consumed by Americans sported the Anheuser Busch eagle...proof that microbreweries notwithstanding, many Americans still favored a light-bodied, effervescent beer of the kind created by...Adolphus Busch more than a century earlier" (Ogle, 2006, p. 337; italics added).

\subsection{Molson Coors: The Runner-up}

As part of AB-In-Bev's settlement to merge with SAB Miller in 2015, Molson Coors (MC) won the global rights to Miller - the company that gave us light lager. In 2008 MC had a $29 \%$ share of the total U.S. beer sales.

MC has two imports, Keystone and Molson, and also the former import George Killian.

In 1995 MC launched Blue Moon, a home-grown craft beer. It is a wheat-based Belgian style white beer that has was the best-selling ale in 2008 .

For 2008 Molson Coors, the mid-price brands produced 79\% of its total beer sales, somewhat higher than that for AB-In-Bev.

\subsection{The Import Group: The Mexican and European Connection}

In 2008 , this group had $15 \%$ of total U.S. beer sales.

10.3.1 The Mexican Connection: Constellation Brands

This group is represented by Constellation Brands (CB), a U.S. company. It has four brands in its stable: Corona, Modelo, Negra Modelo, and Pacifico. CB's 2008 market share was 7.8\%. It was created in 2013 when AB-In-Bev had to sell Grupo Modelo's U.S. business to CB due to anti-trust concerns.

Corona was the best-selling import in America in 2008 and a lofty rank \#5 with the best-selling lager brands in 2008 .

Looking at these imports provided us with an interesting insight. According to our 2008 lager sales data for the 12-pack, all four of these imports, like most others imports, are members of the premium segment. However, all except Negra Modelo sell regular or standard American Adjunct lagers (AAL) — just like Budweiser.

The question is why Corona sells at a premium price, but Budweiser at mid-price? One answer may be that Corona is perhaps a beneficiary of the import mystique. Second, according to Green's website premium ALLs use about $25 \%$ of adjuncts compared to as much as $40 \%$ for standard or regular lagers. Also, they are likely to be higher in "hop aroma and flavor..." (Retrieved November 2, 2017, from 
http://www.greensbeverages.com/alcohol-u/type/american-adjunct-lager).

Interestingly, Corona was introduced as an import in USA in 1981. However, in Mexico it used to be a workers' beer; but since then it has moved up the ladder to the status of a premium beer and the best-selling import in America (Adelson, 1987).

10.3.2 The European Connection: The Heineken Group

Heineken Nederland group symbolizes the European connection. In 2008, it had 6.8\% share of the U.S. beer sales.

In 2008 Heineken was the biggest seller of "all malt" lager with a 4\% share, and ranking \#6 among top-selling lager brands.

The Heineken group has several import brands under its umbrella including the Mexican beers Tecate and Dos Equis; Netherland's Amstel, and English Newcastle ale.

It has also acquired a 50\% share in the former craft brand, Lagunitas.

Finally, $83 \%$ of Heineken group's 2008 beer sales were produced by brands in the premium segment.

\subsection{The "Craft" Group}

"There's never been a better time to be a beer drinker in America. The skillful innovation of American craft brewers over the past decade has pushed beer in delicious new directions. It won't be hard to argue that craft beer renaissance is the most exciting development in the country's culinary world right now" (Satran, 2014).

This group consists of brands that are members of the Brewers Association [of America] that represents small and independent brewers. In 2008 this group had a U.S. beer market share of $6.2 \%$, as per our data.

As we have noted earlier, craft brewers generally favor ale because craft beer lovers usually prefer it over lager. Another factor is that producing lagers is far more challenging. Yet, in 2008 craft ale dollar sales were not much higher than craft lager sales: with a share of $54 \%$ vs. $46 \%$. This is because two brands alone - Samuel Adams and Yuengling—sold 70\% of 2008 craft lager.

These two had climbed to the top tier of lager brands occupying $12^{\text {th }}$ and $19^{\text {th }}$ spots, respectively.

In 2008 craft beers were the only group that sported brands in the super-premium category which recorded 3\% of craft beer sales, while the share of premium segment was $72 \%$.

\subsection{Minor Players}

The "Minor Players" group consists of two players: The Pabst group and the Labatt group. In 2008 their U.S. beer market share was 3.4\%.

10.5.1 The Pabst Group: "Resurrecting the Dead"

Pabst has embarked on a strategy of "resurrecting the dead" by reinventing old beer brands Stroh's, Old Style, and Schlitz, Other brands in its portfolio are Old Milwaukee, Colt 45, Blatz, and so on. The company thinks that "variety-seeking craft beer-crazed drinkers will develop an appetite for the classics" (Schultz, 2016).

The group had a U.S. beer market share of $2 \%$ in 2008 . 
In 2008 the economy segment generated $93 \%$ of the group's sales.

\subsubsection{The Labatt Group}

This group is actually owned by North American Brewers (NAB) of which Labatt, a Canadian company, is by far the biggest. The group has also acquired former craft brands Magic Hat and Pyramid (NAB. Retrieved November 21, 2017, from http://www.nabreweries.com/about/).

In 2008 NAB's U.S. beer market share was $1.4 \%$.

Of the group's total U.S. beer sales for 2008, two-third of them came from the mid-price segment-mainly on the shoulders of Labatt.

\section{Why is American Adjunct Lager-Light and Regular-Popular Globally?}

\subsection{Americans Now Have an Immense Variety in Beer}

In a painstaking, scholarly work that goes as far back as the beginning of the $17^{\text {th }}$ century, Dighe (2016) suggests that the unusually strong temperance movement in America put the industry on the defensive. In response, brewers began to market their beer as the "beverage of moderation". Consequently, consumers "sought out light, relatively non-intoxicating beers". He adds that "the recent craft beer revolution is a "backlash against this kind of beer".

Thanks to Dighe's insight, we ought to be thankful to the beer industry management for discouraging excessive drinking, as any responsible citizen would.

As we have mentioned before, the sixties gave rise to two historic developments: the emergence of the import and craft segments in the beer industry. From their infancy in the 1960s, both have now entered a maturity phase. Presently, consumers face a bewildering array of choices from: pale to dark; adjunct lager to all-malt lager; light-body to full-body; low alcohol/calories to high alcohol/calories (Note 8); beers from Mexico, Europe, or China; traditional, import, or craft; lager or ale; light lager or American strong ale; and so on.

"The U.S. beer culture now is the one with the greatest variety and highest level of inventiveness in the world, not to mention the extraordinary quality achieved by the best which certainly rivals the best of the Old World" (Reddit Beer. https://www.reddit.com/r/beer/comments/22czdh/why_are_lightlite_beers_so_popular_in_the_united/).

\subsection{The Global Popularity of Traditional American Beer}

We looked at the 10 best-selling brands in the world. We found the results to be really eye-opening (Business Insider. Retrieved November 16, 2017, from http://www.businessinsider.com/10-biggest-selling-beer-brands-globally-2016-5).

It is interesting to see that seven out of ten are traditional American Adjunct lagers including two light brands; and three are American brands, of which two-Bud Light and Budweiser-occupy the lofty positions of \#3 and \# 4, with \#10 Coors Light bringing up the rear (ibid).

But there is more. The best-selling beer in Mexico is Corona; it is Budweiser in Canada, and Carling in Great Britain. All three are American Adjunct lagers! (Vinepair. 
https://www.vinepair.com/wine-blog/most-popular-beer-every-country-map/).

The stunning nature of the above piece of data prompts us to the conclusion, that while these best-selling American Adjunct lagers have not been able to secure the "Good Housekeeping" seal of approval from America's craft brewers, beer experts and connoisseurs, yet, the consumers in America — and the world - have resoundingly voted for them with their pocket books!

We have mentioned before, that in the early 1950s the American brewers began to produce beer that was pale, with mild hop flavor, and no bitter after-taste. Then the president of the Wahl-Henius Institute — one of the leading beer schools—warned brewmasters (Ogle, 2006, p. 229):

[While] they might prefer full-bodied, hoppy brews, but they weren't the ones buying beer. The public preferred "blandness", and so blandness it must have.

\subsection{Anheuser Busch: Rice for Better Quality, Not Lower Cost}

Let us go back to the time before 1876 when the first American Adjunct lager-Budweiser-was born. As we have reported earlier, Anton Schwartz and Dr. Siebel—based on their research—-had concluded that malt adjuncts did not make beer inferior.

Then Adolphus Busch was trying to respond to several challenges: shortage of barley; American-grown six-row barley was too rich in protein; it was unstable, and it had a short shelf life, so beer could not travel long distances. And adjunct-based Budweiser met all those challenges.

It is also important to point out that Adolphus Busch did not choose rice as an adjunct to lower cost. On the contrary, rice cost more to produce beer at that time, yet he did not waver from his dream to launch his revolutionary creation.

Finally, as we have observed before, Adolphus Busch chose rice as an adjunct because he believed it lent crispness and clean taste to beer. He thought Budweiser, because of its smoothness and drinkability, was perfect for the hot summers of St. Louis.

\subsection{Craft Brewers: Shifting Attitudes towards Rice}

In the words of Maureen Ogle, rice is "considered by many[craft] brewers what nasty industrial brewers use to water down their beer", and craft "brewers treat rice almost as if it's rat poison". She says the anti-rice attitude goes back to early craft brewing revival in the 1980s. With a sense of superiority, many craft brewers thought we are "not like those industrial brewers making watered-down, cheap beer by using adjuncts like rice" (Garbee, 2009; italics added).

But now several craft brewers in California, Colorado, and Washington are challenging this orthodoxy, and introducing "complex, full-flavored rice beers. They say "rice can lend subtle tropical notes and a bright finish to their lagers and ales" (ibid).

One brewer pointed out that although rice gives beer a light body, it also makes beer crisp, refreshing, and a little fruity (ibid).

The negative attitude among early craft brewers toward adjuncts is now changing. They are finding that by moderating the use of adjuncts they can produce "high-quality, light-bodied, session beers" (Talley, 2017, p. 77; for a discussion of what session beers are see the next section). This shift in outlook is 
reflected by a change in Brewer Association's (BA) policy. As we have reported before, BA now allows the use of adjuncts, like rice and corn, so long as they are used to enhance flavor.

\subsection{Session Beers: Flavor and Balance}

Session beer is a modern term that has been recognized since 1982, although session beers have been brewed the world over for hundreds of years (Talley, 2017, p. 7).

"Session beer is not defined by flavors or aromas, which can place it in almost any category. Instead, what makes a session beer is primarily refreshment and drinkability (italics added) (Retrieved November 21, 2017, from https://www.craftbeer.com/styles/session-beer).

The goal of session beer is to strike a balance between lower alcohol content and the style's character of which drinkability is an essential trait. The session beer must be "enjoyable to drink multiple pints of in a single sitting and be relatively low in alcohol" that should not exceed 5\% ABV (Note 9). It must "unequivocally be made of high quality ingredients; low alcohol alone does not make a session beer" (Talley, 2017, p. 8).

A session beer is one that "makes you enjoy the company, the conversation - and the beer. It is a beer that by the end of the evening one "looks forward to repeating the experience again" (ibid, p. xiii).

\subsection{High-quality Craft Beer Comes at a Cost}

American craft beers are known for their high quality. Yet, this high quality comes at a cost. For example, based on our sales data for 2008, the price of a 12-pack Anchor Steam lager was 69\% higher than that of Budweiser, and Samuel Adams lager $41 \%$ higher.

One reason for higher craft beer prices is that customers expect to pay more, thanks to craft mystique. Second, most craft brewers, because of their small size, do not have the economies of scale of macro brewers. In particular, more than $50 \%$ of the price of a $\$ 12$ craft six-pack is eaten up by distributor's and retailer's margins (Satran, 2014).

We suggest that a very important factor behind continued popularity of American Adjunct lagers is their moderate-to-low prices: with mid-price brands like Bud Light, Miller Light, Coors Light and Budweiser; and economy brands like Busch Light and Natural Light (Table 1).

\subsection{Fike's Framework for Classifying Beer: Light vs. Dark Beers}

As everyone knows, beauty lies in the eyes of the beholder. Similarly, different people have different tastes in beer. Moreover, even the type of beer people prefer may be different from one time or situation to another.

One problem every consumer faces is how to compare one kind of beer with another? Fike (2015) has come up with a smart framework that is both meaningful and practical. He has divided beer in two broad categories: light vs. dark. They include both light and regular beers; adjunct and all-malt beers; craft as well as imported beers; and lagers and ale beers - all side by side.

In the light group he has included such brands as Samuel Adams Light, Heineken, Corona, and Sierra Nevada Summerfest.

Some of the beers included in the dark group are Guinness, Modelo Negro, and Dogfish Head 90 
Minute IPA (India Pale Ale).

Fike (2015) points out the following differences between light and dark beers:

- Light beers have less calories and alcohol compared to dark beers.

- Light beers have lighter color and flavor; dark beers have a much fuller flavor.

- Light beers are more refreshing and less filling; dark beers are more filling.

- Light beers have a crisp, light aroma; dark beers are more pungent.

- Dark beers are preferred by enthusiasts: they are meant to be "sipped and savored".

- Light beer drinkers usually drink them while doing other things - and still have a good time.

- Light beers go well with activities: parties, outdoor events, social gatherings-especially during summer.

- Dark beers fill and warm you up; best time to drink them is during colder seasons.

- Light beer drinkers have a very large following because light beers have high drinkability; they are easy to drink and can be quite thirst-quenching.

- Dark beer drinkers are a small group, because dark beers are "heavy and leave a strong, lingering aftertaste" (ibid, italics added).

11.8 Alcohol-Based System for Classifying Beer: Low vs. High

The beer style classification system, that is almost universally followed in this country, is based, among others, on factors like country of origin, color of beer, or the type of ingredients. Whether consciously, or unconsciously, it has put an unfair burden on traditional American beer-Pale Adjunct Lager-by lending it an image of inferiority.

This system is based on an orthodox assumption that a good quality beer should only be made from barley malt without any adjuncts. But, today this rigid requirement is creating new problems. For example, the successful Blue Moon Belgian White Ale has no adjuncts because it is made entirely out of wheat.

However negative attitudes toward adjuncts are now changing. So some craft brewers, recognizing the qualities of rice, are offering complex, full-flavored rice beers. Also the Brewers Association is now going to allow adjuncts so long they are meant to enhance flavor.

In view of the above, we are proposing a system of classifying beer based on just one factor: alcohol - from low to high. But, as we have indicated earlier, calories and alcohol usually go together. So in making light beer, the effort to reduce calories reduces alcohol at the same time.

In Table 3 we have classified 50 popular brands in four broad categories by level of alcohol—from low to high, along with number of calories. The list includes light and regular beers, ales and lagers, imports, craft, and traditional beers.

But some brands may not quite fit the pattern of close association between alcohol and calories, so it may be difficult to choose between alternatives. However, focusing on the two together may provide a trade-off between the two to resolve the issue: 
- $\quad$ For example, Samuel Adams Light has the lowest ABV of 4.0, but a higher calorie count of 128, compared to Miller Lite's ABV of $4.17 \%$, and 96 calories.

- Another interesting case is that of Bud Light Platinum. Its calories are $15 \%$ higher than those of Coors Light, but its alcohol ABV is much higher: $43 \%$.

To test the hypothesis that alcohol and calories are closely related, we performed bivariate correlation on the two variables. To our great surprise, all three measures of correlation-Pearson, and non-parametric measures, Kendall's tau_b, and Spearman's rho_-were found to be significant at an amazing 0.01 level!

Table 3. An Alcohol-Based System of Classifying Beer

\begin{tabular}{|c|c|c|c|}
\hline Name Of Brands and ABV & Beer Style & $\mathrm{ABV} \%$ & Calories \\
\hline \multicolumn{4}{|l|}{ Non-alcohol: Under $1 \%$} \\
\hline O’Doul's Non-alcoholic Lager & Non-alcoholic Beer & 0.50 & 90 \\
\hline \multicolumn{4}{|l|}{ Low: Under $4.5 \%$} \\
\hline Shiner Light Lager & Light Lager & 4.00 & 99 \\
\hline Abita Light Lager & Light Lager & 4.00 & 118 \\
\hline Samuel Adams Light Lager & Light Lager & 4.00 & 128 \\
\hline Amstel Light Lager & Light Lager & 4.10 & 95 \\
\hline Busch Light Lager & Light Lager & 4.10 & 95 \\
\hline Corona Light Lager & Light Lager & 4.10 & 99 \\
\hline Keystone Light Lager & Light Lager & 4.10 & 104 \\
\hline Miller Light Lager & Light Lager & 4.17 & 96 \\
\hline Michelob Ultra Light Lager & Light Lager & 4.20 & 95 \\
\hline Natural Light Lager & Light Lager & 4.20 & 95 \\
\hline Milwaukee's Best Light Lager & Light Lager & 4.20 & 98 \\
\hline Heineken Light Lager & Light Lager & 4.20 & 99 \\
\hline Bud Light Lager & Light Lager & 4.20 & 110 \\
\hline Bud Light Lime Lager & Light Lager & 4.20 & 116 \\
\hline Coors Light Lager & Light Lager & 4.20 & 119 \\
\hline Guinness Draught Ale & Irish Dry Stout Ale & 4.20 & 125 \\
\hline \multicolumn{4}{|l|}{ Moderate: $4.5-5.9 .0 \%$} \\
\hline Yuengling Traditional Lager & American Amber/Red Lager & 4.50 & 128 \\
\hline Miller High Life Lager & American Adjunct Lager & 4.60 & 143 \\
\hline Corona Extra Lager & American Adjunct Lager & 4.60 & 148 \\
\hline Dos Equis Amber Lager & Vienna Lager & 4.70 & 130 \\
\hline Newcastle Brown Ale & English Brown Ale & 4.70 & 140 \\
\hline
\end{tabular}




\begin{tabular}{|c|c|c|c|}
\hline Firestone Pale Ale & American Pale Ale & 4.80 & 147 \\
\hline St. Pauli Girl Lager & German Pilsner & 4.90 & 148 \\
\hline Widmer Bros. Ale & Hefeweizen & 4.90 & 156 \\
\hline George Killian's Irish Red Lager & American Amber/Red Lager & 4.90 & 162 \\
\hline Bavaria Lager & German Pilsner & 5.00 & 140 \\
\hline Stella Artois Lager & Euro Pale Lager & 5.00 & 141 \\
\hline Heineken Lager & Euro Pale Lager & 5.00 & 142 \\
\hline Budweiser Lager & American Adjunct Lager & 5.00 & 145 \\
\hline Beck's Lager & German Pilsner & 5.00 & 146 \\
\hline Name Of Brands and ABV & Beer Style & ABV \% & Calories \\
\hline Michelob (Original) Lager & American Pale Lager & 5.00 & 150 \\
\hline Deschutes Mirror Pond Pale Ale & American Pale Ale & 5.00 & 170 \\
\hline Samuel Adams Boston Lager & Vienna Lager & 5.00 & 175 \\
\hline Pyramid Ale & Hefeweizen & 5.20 & 145 \\
\hline Michelob Amber Bock Lager & Bock & 5.20 & 152 \\
\hline Fat Tire Amber Ale & American Amber/Red Ale & 5.20 & 155 \\
\hline Brooklyn Lager & American Amber/Red Lager & 5.20 & 156 \\
\hline Alaskan Amber Ale & Altbier & 5.30 & 159 \\
\hline Blue Moon Belgian White Ale & Witbier & 5.40 & 171 \\
\hline Sierra Nevada Pale Ale & American Pale Ale (APA) & 5.60 & 175 \\
\hline Redhook ESB Ale & Extra Special/Strong Bitter Ale & 5.80 & 179 \\
\hline \multicolumn{4}{|l|}{ Moderately High: 6.0-6.9\% } \\
\hline Bud Light Platinum Lager & Light Lager & 6.00 & 137 \\
\hline Bass Pale Ale & English India Pale Ale (IPA) & 6.00 & 160 \\
\hline Sierra Nevada Celebration Ale & American India Pale Ale (IPA) & 6.80 & 214 \\
\hline Stone Ale & American India Pale Ale (IPA) & 6.90 & 367 \\
\hline \multicolumn{4}{|l|}{ High: $7.0 \%$ and above } \\
\hline Arrogant Bastard Ale & American Strong Ale & 7.20 & 187 \\
\hline Steel Reserve High Gravity Lager & American Malt Liquor & 8.10 & 222 \\
\hline Lagunitas Imperial Pils Lager & American Double/Imperial Pilsner & 8.60 & 249 \\
\hline Dogfish Head 90 Minutes Ale (IPA) & American India Pale Ale (IPA) & 9.00 & 294 \\
\hline
\end{tabular}

\section{Conclusion}

This project has taken us through a long, arduous and challenging journey that has nevertheless been both exhilarating and rewarding. The U.S. beer industry is extremely complex, especially for an outsider. So, we have made every effort to explain its history, and discuss its competitive dynamics. But, while being an outsider can be a handicap, it can also be an advantage because of the objectivity an Published by SCHOLINK INC. 
outsider can bring to the table.

Through the extraordinary generosity of A.C. Nielsen Co. we were fortunate to get the U.S. beer retail sales data for 2008 and 2007. For 2008 total U.S. beer sales were \$9.5 Billion.

The primary thesis of this paper is that a business seeking market-share leadership should serve the middle class by competing in the mid-price segment at a price somewhat higher than the nearest competition. This is the segment that Procter \& Gamble has successfully served in the past. It is also the socio-economic segment that encompasses about $40 \%$ of the U.S. population.

The lager segment garnered a massive $92 \%$ share of the 2008 sales. So, focusing on this segment, we chose hierarchical cluster analysis to test the hypotheses that: (1) the market share leader is going to be a member of the mid-price segment, and (2) its unit prices are going to be somewhat higher than those of the nearest competition.

In order to test the validity of our results, we decided to conduct our analysis not just for one pack but two - the 12- and six-packs - and not only for 2008, but for 2007 as well.

We could not believe our eyes when we found that the results of all four analyses supported both of our hypotheses!

First, we found that Bud Light was the market leader, followed by Miller Light: and both were members of the mid-price segment. Second, for both packs, the unit prices of Bud Light were higher than those of Miller Light, but not by much. The biggest four market share holders-the "Big Four"-were Bud Light, Miller Light, Budweiser, and Coors Light.

We have included the former imports in the "Import" group. Similarly, the "Craft" group also includes former crafts, and home-grown craft-like beers.

The results revealed that members of the "Craft" and "Import" groups were primarily part of the premium segment. For the total beer market for 2008, the traditional group, the "Import" group and the "Craft" group had shares of 68\%,23\%, and 9\%, respectively.

In 2008 light adjunct lager had an amazing market share of 55\%, followed by $31 \%$ for regular adjunct lager.

Next we found that the large brands relied heavily on promotion. So we looked at 33 brands with 2008 lager sales of over $\$ 25$ million. On average, the promotional sales were $48 \%$ of total lager sales. The two biggest users were the premium "Import' group, followed by the "Big Four" from the mid-price segment.

We found five strategic groups in the industry in 2008. These were: (1) AB-In-Bev, the market leader, with a 43\% market share, (2) Molson Coors, the runner-up with a 29\% share; (3) The Imports group with a 15\% share; (4) The Craft group with a 6\% share, and (5) Minor players with a 3\% share.

The first event that transformed the history of the industry was the birth of Budweiser in 1876: the first American beer that contained rice as an adjunct. This is because the American customers loved the revolutionary, lighter lager that millions of customers worldwide still like today. This beer was such a big success that it changed the face of the U.S. beer industry, and did so almost overnight. 
The next transforming event was the introduction of light beer by Miller in 1972; by 2005 production of light beer had bypassed that of regular beer.

Third, it is the phenomenal expansion of the premium "Import" market that has grown from a share of $1 \%$ in 1960 s to $23 \%$ in 2008 , as per our data.

Fourth is birth of the craft movement in 1965, spearheaded by Fritz Maytag of Anchor Brewing Co., who decided to produce "older style of full-bodied" high-quality beer aimed at discriminating customers. In 2016 the crafts had a market share of $12.3 \%$.

Among many craft brewers and experts in the industry, there is an impression that the traditional American Adjunct lagers - represented by Budweiser, Bud Light, and others - are bland. The question is then why are they so popular? We discovered that seven of the top 10 global beer brands are American Adjunct lagers: with Bud Light and Budweiser occupying the towering slots \#3 and 4, and Coors Light at \#10. Furthermore, the top-selling beers in Mexico, Canada, and Great Britain are also American Adjunct lagers. Also, the top-selling Mexican import in USA, Corona is American Adjunct lager, for which Americans are willing to pay even premium prices.

However, this negative attitude toward adjuncts is now changing. Brewers Association (BA), an arm of craft brewers, has changed its policy, and now permits the use of adjuncts, like rice and corn, so long as they are used to enhance flavor.

Whether consciously, or not, the beer style classification system commonly used by the industry has put an unfair burden on the traditional American beer-Pale Adjunct Lager-by imparting it an image of inferiority. So, we have proposed a beer classification system based just on level of alcohol: from low to high. It is based on the idea that, in general, trying to reduce calories simultaneously reduces alcohol as well.

To test this hypothesis, we chose 50 of the most popular brands-lagers and ales, traditional, imports, and craft - that run the gamut of alcohol content from low to high. Then we performed bivariate correlation on the two variables.

To our great astonishment, all three measures of correlation were found to be significant at an amazing 0.01 level!

We found increasing globalization and concentration in the American beer market in which the largest two companies controlled more than $70 \%$ of the market in 2008. We have identified five strategic groups. Their market shares were: AB-In-Bev 43\%, Molson Coors 29\%, the Import group 15\%, Crafts 6\%, and Minor Players 3\%.

Heavy concentration notwithstanding, the U.S. beer market has never been more competitive. Today the import and craft segments have grown big enough to be a force to reckon with. Now the U.S. beer culture is the one with the greatest variety and highest level of creativity in the world.

Finally, about a hundred years ago, General Motors came up with a brilliant idea: "a car for every purse and purpose". We would like to offer a different variation of this theme. And that is: "a beer for every purse, for every taste, and for every situation, or time". 


\section{Acknowledgments}

We are immensely grateful to A.C. Nielson Co. for their immense generosity for the invaluable U.S. national sales data of the U.S beer industry for 2008 and 2007 without which this ambitious project would not have been possible.

We are also greatly indebted to Maureen Ogle for her brilliant book Ambitious Brew which was invaluable in our understanding of the long history of the U.S. beer industry-and its subtleties.

Finally, we owe enormously to Beer Advocate for using their style codes of the beer industry, and relying extensively on profiles of hundreds of individual beer brands from their vast library.

\section{References}

Adelson, A. (1987). A workers' beer gains status. New York Times, July 11.

Beer Advocate. (2001). History of American beer. Retrieved November 16, 2017, from http://www.advocate.com//101/history_american_

Cision PRWEB. (2013). USA market insights 2013 report. October 10. Retrieved November 16, 2017, from http://www.prweb.com/releases/2013/10/prweb11219166.html

Datta, Y. (1996). Market segmentation: An integrated framework. Long Range Planning, 29(6), 797-811. https://doi.org/10.1016/S0024-6301(97)82817-8

Datta, Y. (2010a). A critique of Porter's cost leadership and differentiation strategies. Chinese Business Review, 9(4), 37-51.

Datta, Y. (2010b). Strategic group theory: A customer-oriented view. Chinese Business Review, 9(7), $11-26,36$.

Datta, Y. (2010c). Maslow's hierarchy of basic needs: An ecological view. Oxford Journal, 10(1), 39-57.

Datta, Y. (2011). Rising economic inequality and class divisions in America: A socio-economic class lifestyle profile. Oxford Journal, 11(1), 1-25.

Datta, Y. (2012). The U.S. men's shaving cream market: A competitive profile. Chinese Business Review, 11(1), 44-64.

Dighe, R. S. (2016). A taste of temperance: How American beer got to be so bland. Business History, 38(5), 752-784. https://doi.org/10.1080/00076791.2015.1027691

Fike, J. (2015). The battle between light and dark beer. Retrieved November 16, 2017, from http://www.sundial.csun.edu/2015/03/the-battle-between-light-and-dark-beer/

Forbes. (2015). AB-InBev and SABMiller merger focuses on markets outside the U.S. Retrieved November 16, 2017, from https://www.forbes.com/sites/greatspeculations/2015/11/16/ab-inbevand-sabmiller-merger-focuses-on-markets-outside-the-u-s/\#e44a0e64713a

Gale, B. T. (1992). Quality comes first when hatching power brands. Planning Review, July-August, 4-9. https://doi.org/10.1108/eb054361

Garbee, J. (2009). Craft brewers rethink rice in beer. LA Times, Sept. 30. Retrieved November 21, 2017, 
from http://www.articles.latimes.com/2009/sep/30/food/fo-beer30

Gribbins, K. (2017). 2017 mid-year U.S. craft beer analysis: 5\% growth shows a slowing, maturing market. Retrieved November 16, 2017, from https://www.craftbrewingbusiness.com/ featured/craft-beer-growth-shows-slowing-maturing-market/

Ketchen, Jr., D. J., \& Shook, C. L. (1996). The application of cluster analysis in strategic management research: An analysis and critique. Strategic Management Journal, 17, 441-458. https://doi.org/10.1002/(SICI)1097-0266(199606)17:6\%3C441::AID-SMJ819\%3E3.0.CO;2-G

Knoedelseder, W. (2012). Bitter Brew: The rise and fall of Anheuser-Busch and America's kings of Beer. New York: Harper Collins Publishers.

Lafley, A. G., \& Charan, R. (2008). The game changer: How you can drive revenue and profit growth with innovation. New York: Crown Business.

Marriott, M. (1993). For minority youths, 40 ounces of trouble. New York Times, Apr. 16. Retrieved November 16, 2017, from http://www.nytimes.com/1993/04/16/nyregion/for-minority-youths-40ounces-of-trouble.html?pagewanted=all

McLaughlin, D. (2016). U.S. clears way for $\$ 101$ billion AB InBev-SABMiller mega. Retrieved November 16, 2017, from http://www.chicagotribune.com/business/ct-ab-inbev-sabmillerantitrust-approval-20160720-story.html

Mosher, R. (2009). Tasting Beer: An insider's guide to the world's greatest drink. North Adams, MA.

Nachel, M., \& Ettlinger, S. (2012). For dummies. Hoboken, N.J.: John Wiley \& Sons, Inc

Ogle, M. (2006). Ambitious Brew: The story of American beer. Orlando, FL: Harcourt, Inc.

Oliver, G. (Ed.). (2012). The Oxford companion to beer. New York: Oxford University Press.

Pollan, M. (2008). In defense offood: An eater's manifesto. New York: The Penguin Press.

Pollan, M. (2009). Omnivore's dilemma: The secrets behind what you can eat. New York: Dial Books.

Pomranz, M.(2017). What makes light beer different from all other beer? Retrieved November 16, 2017, from http://www.foodandwine.com/fwx/drink/what-makes-light-beer-different

Porter, M. E. (1980). Competitive strategy. New York: Free Press.

Porter, M. E. (1992). Capital disadvantage: America's failing capital investment system. Harvard Business Review, 70(5), 65-82.

Satran, J. (2014). Here is how a six-pack of craft beer ends up costing \$12. Huffington Post, Sept. 12. Retrieved November, 2017, from https://www.huffingtonpost.com/2014/09/12/craft-beerexpensive-cost_n_5670015.html

Schultz, E. J. (2016). How Pabst is reinventing Stroh's, Old Style, Schlitz. Retrieved November 16, 2017, from http://www.adage.com/article/cmo-strategy/pabst-reinventing-stroh-s-style-schlitz/ $305538 /$

Science News. (2005). Malt liquor beers, and the people who drink them are different. Retrieved November 16, 2017, from https://www.sciencedaily.com/releases/2005/03/050326115140.htm

Stack, M. H. (2003). A concise history of America's brewing industry. Retrieved November 20, 2017, from Published by SCHOLINK INC 
https://www.eh.net/encyclopedia/a-concise-history-of-americas-brewing-industry/

Talley, J. (2017). Session beers: Brewing for flavor and balance. Boulder, Col.: Brewers Publications.

Taylor, K. (2017). Craft brewers are calling for the boycott of these 14 "imposter" brands. Retrieved November 16, 2017, from http://www.businessinsider.com/craft-brewersboycott-brands-acquired-by-anheuser-busch-2017-5/\#1-goose-island-1https://www.google.com/?g ws_rd=ssl

USA Today. (2015). Yuengling ousts Boston as top U.S. craft brewery, March 31. Retrieved from https://www.google.com/search?ei=w-YNWq6KBsKRmQHgiabQBQ\&q=Yuengling+ousts+Bosto n++as+top+U.S.+craft+brewery\&oq=Yuengling+ousts+Boston++as+top+U.S.+craft+brewery\&gs _l=psy-ab.3...7509.16757.0.20194.1.1.0.0.0.0.142.142.0j1.1.0...0...1.1.64.psy-ab..0.0.0....0.PczQy EJMgIQ

Webb, T., \& Beaumont, S. (2012). The world atlas of beer: The essential guide to the beers of the world. New York: Sterling Epicure.

\section{Notes}

Note 1. In this study reference to all pack sizes is based on 12oz. cans or bottles.

Note 2. This data is from food stores (supermarkets) with sales of over $\$ 2$ million, and drug stores over \$ 1 million; it also includes discount stores, such as Target and K-Mart, but excludes Wal-Mart as well as warehouse clubs, e.g., Sam's Club, Costco, and BJ's. It also does not include the "dollar" stores, such as Dollar General, and others.

Note 3. For those stores for which, during a week, there were feature ads, coupon ads, display, or temporary price decrease of at least $5 \%$.

Note 4. We are grateful to Prof. Ravi Chinta of Xavier University, Cincinnati for transporting a considerable part of the raw data to Excel format. We are also indebted to Austin Elkins of NKU's IT dept. for technical assistance.

Note 5. The six classes are: "The Poor", "The Near Poor", "Traditional Middle Class", "The Upper-Middle Class", "The Very Rich/The Rich", and "The Mega Rich-Masters of the Universe".

Note 6. The market share data is based on total U.S. retail sales for 2008 - lager and ale —of $\$ 9.5$ Billion.

Note 7. A pack means that every can or bottle contains $12 \mathrm{oz}$.

Note 8 . Because the two are closely related.

Note 9. Alcohol By Volume. 